\title{
The Empirical Bases for the Earth3 Model: Technical Notes on the Sustainable Development Goals and Planetary Boundaries
}

David Collstei, Jorgen Randers ${ }^{\mathrm{ii}}$, Ulrich Goluke ${ }^{\mathrm{iii}}$, Per-Espen Stoknes ${ }^{\mathrm{ii}}$, Sarah E. Cornelli , Johan Rockström ${ }^{\mathrm{i}}$

This technical note contains supplemental material to the report by Randers et al (2018) Transformation is Feasible, How to achieve the Sustainable Development Goals within Planetary Boundaries, a report to the Club of Rome, Stockholm: SRC., as well as to the scientific paper Randers et al (2018) "Achieving the Sustainable Development Goals within Planetary Boundaries", in preparation to Global Sustainability.

\begin{abstract}
This technical note presents the bases for the Earth3 model system with a focus on how SDGs and Planetary Boundaries are assessed in the model. This includes data selection, sources, analysis and forecasting methods. We also present the threshold levels that have been chosen for the respective SDGs and Planetary Boundaries.
\end{abstract}

\section{Key words:}

Sustainable Development Goals, Agenda 2030, Planetary Boundaries, Safe Operating Space, Doughnut Economics

\section{Introduction: Data selection, sources, analysis and forecasting methods}

Our starting point is the 17 Sustainable Development Goals agreed by the UN in 2015. Table 1 lists the modelled indicators we have used to track the degree to which the 17 SDGs are achieved, by region. The indicators were chosen based on goal formulations in the resolution ${ }^{1}$, data availability and compatibility with the processes in our model system, the SDG Index and Dashboards Report 2016 and 2017², and further modified by the project team. Details on each SDG are presented in section 2 below. Details on the planetary boundaries are presented in section 3 . We use the seven world regions as specified in section 4 , and weight by population size when aggregating (the primary) national data to regional levels.

In general, the following procedure has been followed with some alterations for the different SDGs as specified under each goal:

- We present the historical data as a function of GDP per person (GDPpp, measured in 2011 Purchase Power Parity adjusted US\$ with data from the Penn World Tables). Country data has been averaged over five-year periods. As there are shortages of historical data for many countries, we have averaged the numbers based on the population sizes of countries where data is available, as part of the respective regions.

\footnotetext{
${ }^{i}$ Stockholm Resilience Centre, Stockholm University. Corresponding author: david.collste@su.se

ii BI Norwegian Business School

iii Blueway
} 
This is this is a non-peer reviewed preprint submitted to EarthArXiv.

- We have then regressed the indicator ( $y$ ) on GDP per person ( $x$ ) - fitting the curve by using a suitable functional form based on soft knowledge and the data analyzed. Normally the formula is $y=a+b^{*} \exp (-c x)$. The reasoning behind this functional form is that we assume that social and economic indicators of progress will initially improve fast as GDPpp grows. Eventually, however, this effect will be balanced by different forms of saturations such as that the whole population has been lifted out of poverty (SDG1) or that electricity access is approaching $100 \%$ (SDG7).

- We use the resulting regressed equations to forecast future values of the indicators.

- In most cases, we use different functions for the seven different regions. We do this based on the assumption that there are characteristics of the regions, such as institutions and distribution, that have been stable over time and will continue to coevolve with GDP per person in a similar way.

Later we may try to improve the regression fit by adding other independent variables (like inequity, government spending per person, or time) to the mathematical formula, to improve the model's forecast (but this would perhaps be at the expense of some of its simplicity). 
This is this is a non-peer reviewed preprint submitted to EarthArXiv.

\begin{tabular}{|c|c|c|c|c|c|c|}
\hline \multicolumn{2}{|c|}{$\begin{array}{c}\text { Sustainable Development } \\
\text { Goals }\end{array}$} & Indicator & Historical data & Forecasting method & $\begin{array}{l}\text { Threshold } \\
\text { value - } \\
\text { green to } \\
\text { yellow }\end{array}$ & $\begin{array}{l}\text { Threshold } \\
\text { value - } \\
\text { yellow to } \\
\text { red }\end{array}$ \\
\hline \multicolumn{2}{|c|}{$\begin{array}{l}\text { The } 17 \text { goals for humanity agreed } \\
\text { by the UN in } 2016\end{array}$} & $\begin{array}{l}\text { Indicator for the achievement of each Sustainable } \\
\text { Development Goal }\end{array}$ & Source of the historical data & $\begin{array}{l}\text { Method used to forecast the indicator } \\
\text { value towards } 2050\end{array}$ & $\begin{array}{l}\text { The } \\
\text { 'target' }\end{array}$ & $\begin{array}{l}\text { 'Halfway } \\
\text { target' - it' }\end{array}$ \\
\hline 1 & No poverty & Fraction of population living below $1.90 \$$ per day (\%) & Worldbank - f(GDPpp), by region & In SDG module - as f(GDPpp), by region & $<2 \%$ & $<13 \%$ \\
\hline 2 & Zero hunger & Fraction of population undernourished (\%) & Worldbank - f(GDPpp), by region & In SDG module - as f(GDPpp), by region & $<7 \%$ & $<15 \%$ \\
\hline 3 & Good health & Life expectancy at birth (years) & Worldbank - $\mathrm{f}(\mathrm{GDPpp}, \mathrm{t})$, by region & $\begin{array}{l}\text { In SDG module - as f(GDPpp, t), by } \\
\text { region }\end{array}$ & $>75$ years & $>70$ years \\
\hline 4 & Quality education & School life expectancy (years) & Worldbank - f(GDPpp), by region & In SDG module - as f(GDPpp), by region & $>12$ years & $>10$ years \\
\hline 5 & Gender equality & Gender parity in schooling (1) & Worldbank - f(GDPpp), by region & In SDG module - as f(GDPpp), by region & $>0,95$ & $>0,8$ \\
\hline 6 & Safe water & Fraction of population with access to safe water (\%) & Worldbank - f(GDPpp), by region & In SDG module - as f(GDPpp), by region & $>98 \%$ & $>80 \%$ \\
\hline 7 & Enough energy & Fraction of population with access to electricity (\%) & Worldbank - f(GDPpp), by region & In SDG module - as f(GDPpp), by region & $>98 \%$ & $>80 \%$ \\
\hline 8 & Decent jobs & Job market growth $(\% / y)$ & Earth3 core - f(GDPpp), by region & $\begin{array}{l}\text { In Earth3 core }(=\text { Growth in GDPpp - } \\
2 \% / y \text {, by region) }\end{array}$ & $>1 \% /$ year & $>0 \% /$ year \\
\hline 9 & Industrial output & $\begin{array}{l}\text { GDP per person in manufacturing \& construction } \\
\text { (2011 PPP US\$/p-y) }\end{array}$ & Earth3 core - f(GDPpp), by region & $\begin{array}{l}\text { In Earth3 core (= GDPpp in 2. sector, } \\
\text { by region) }\end{array}$ & $\begin{array}{l}>6.000 \\
2011 \text { PPP } \\
\text { US\$/p-y }\end{array}$ & $\begin{array}{l}>4.000 \\
2011 \text { PPP } \\
\text { US\$ } / p-y\end{array}$ \\
\hline 10 & Reduced inequality & Share of national income to richest $10 \%(\%)$ & $\begin{array}{l}\text { World Inequality Report - } \mathrm{f}(\mathrm{t}) \text {, by } \\
\text { region }\end{array}$ & $\begin{array}{l}\text { In Earth3 core (= Manual forecast, by } \\
\text { region) }\end{array}$ & $<40 \%$ & $<50 \%$ \\
\hline 11 & Clean cities & Urban aerosol concentration ( $\mu \mathrm{g} 2.5 \mathrm{M} / \mathrm{m} 3)$ & Worldbank - f(GDPpp), by region & In SDG module, f(GDPpp), by region & $\begin{array}{l}<10 \mu \mathrm{g} \\
2.5 \mathrm{M} / \mathrm{m} 3\end{array}$ & $\begin{array}{l}<35 \mu \mathrm{g} \\
2.5 \mathrm{M} / \mathrm{m} 3\end{array}$ \\
\hline 12 & Responsible consumption & Ecological footprint per person (gha/p) & Earth3 core - f(GDPpp), by region & $\begin{array}{l}\text { In Earth3 core (= Ecological footprint } \\
\text { pp, by region) }\end{array}$ & $\begin{array}{l}<1.4 \\
\text { gha/p }\end{array}$ & $<2$ gha/p \\
\hline 13 & Climate action & Temperature rise (deg C above 1850) & ESCIMO - global $f(t)$ & In ESCIMO - as is & $<1 \operatorname{deg} C$ & $\begin{array}{l}<1.5 \operatorname{deg} C \\
\text { (by 2050) }\end{array}$ \\
\hline 14 & Life below water & Acidity of ocean surface water $(\mathrm{pH})$ & ESCIMO - global $f(t)$ & In ESCIMO - as is & $>\mathrm{pH} 8.15$ & $>\mathrm{pH} 8.1$ \\
\hline 15 & Life on land & Old-growth-forest area (Mkm2) & ESCIMO - global $f(t)$ & $\begin{array}{l}\text { In ESCIMO + new old growth forest } \\
\text { sector }\end{array}$ & $\begin{array}{l}>25 \\
\mathrm{Mkm} 2\end{array}$ & $>19 \mathrm{Mkm} 2$ \\
\hline 16 & Good governance & Government spending per person (2011 PPP US\$/p-y) & Earth3-core - f(GDPpp), by region & $\begin{array}{l}\text { In Earth3-core (= Government } \\
\text { spending pp, by region) }\end{array}$ & $\begin{array}{l}>3.000 \\
2011 \text { PPP } \\
\text { US\$/p-y }\end{array}$ & $\begin{array}{l}>2.000 \\
2011 \text { PPP } \\
\text { US\$/p-y }\end{array}$ \\
\hline 17 & More partnership & Exports as fraction of GDP (\%) & Earth3-core - $\mathrm{f}(\mathrm{t})$, by region & $\begin{array}{l}\text { In Earth3-core (= Manual forecast, by } \\
\text { region) }\end{array}$ & $>15 \%$ & $>10 \%$ \\
\hline
\end{tabular}

Table 1: The SDGs, the chosen indicator, data source, forecasting method and threshold values. 
This is this is a non-peer reviewed preprint submitted to EarthArXiv.

\section{Data analysis of the 17 SDGs}

Below we present and briefly discuss the indicators of the respective SDGs and from where data has been retrieved.

\section{SDG1 - No poverty}

For SDG1 - No poverty we use the commonly used definition Fraction of population living below 1.90\$ per day. This indicator is included in the SDG Index and Dashboards Report $2017^{3}$ in relation to SDG1. Also, data availability is good. We have retrieved data per region from the World Bank DataBank ${ }^{4}$ for the following years for the respective regions (displayed in Figure 1):

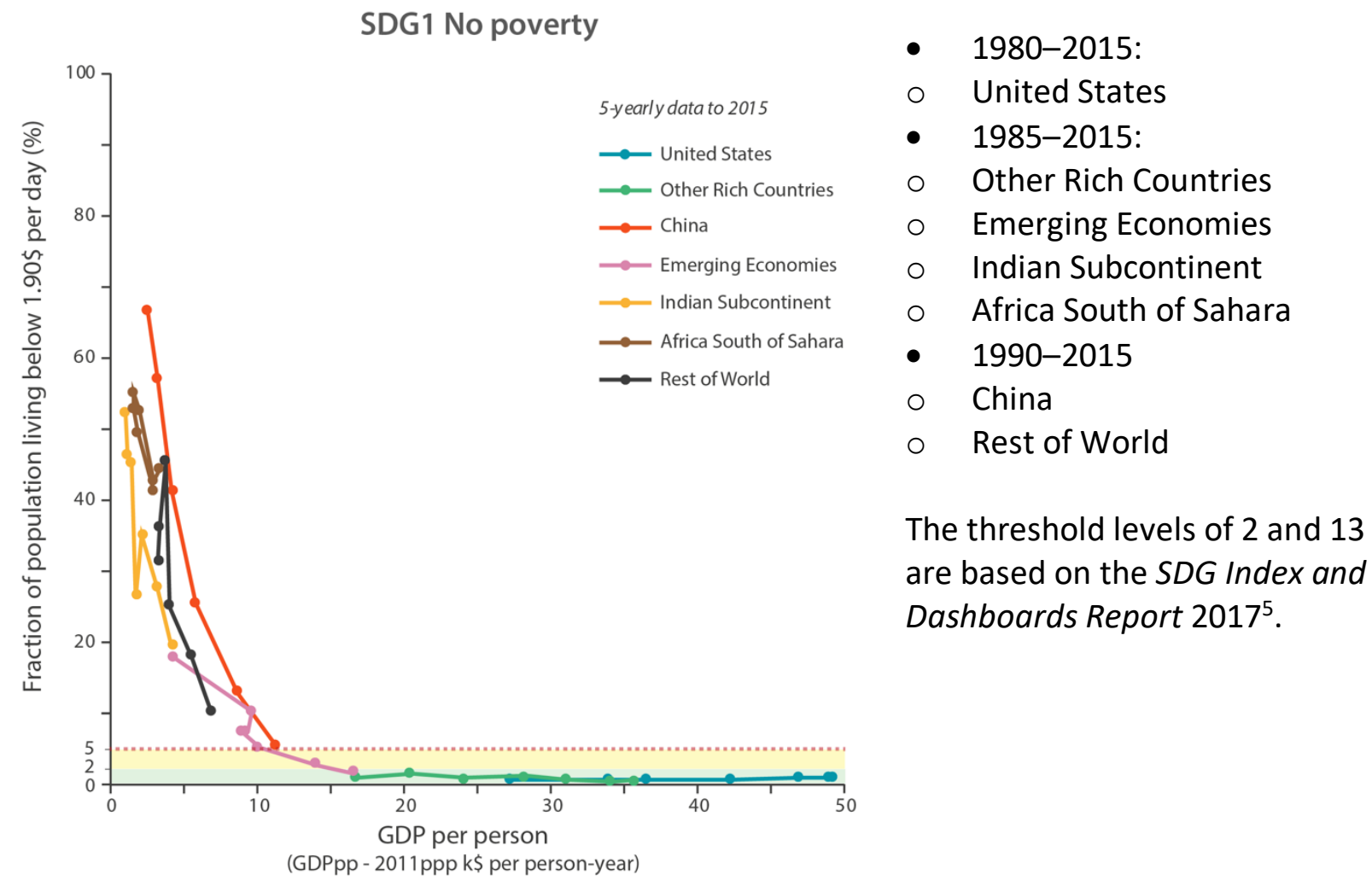

Figure 1: Historical levels of SDG1 No poverty.

The data on SDG1 is performing well around our proposed functional formula:

$$
y=100 * \exp (-x / b) \text {. }
$$

for all regions except China. 


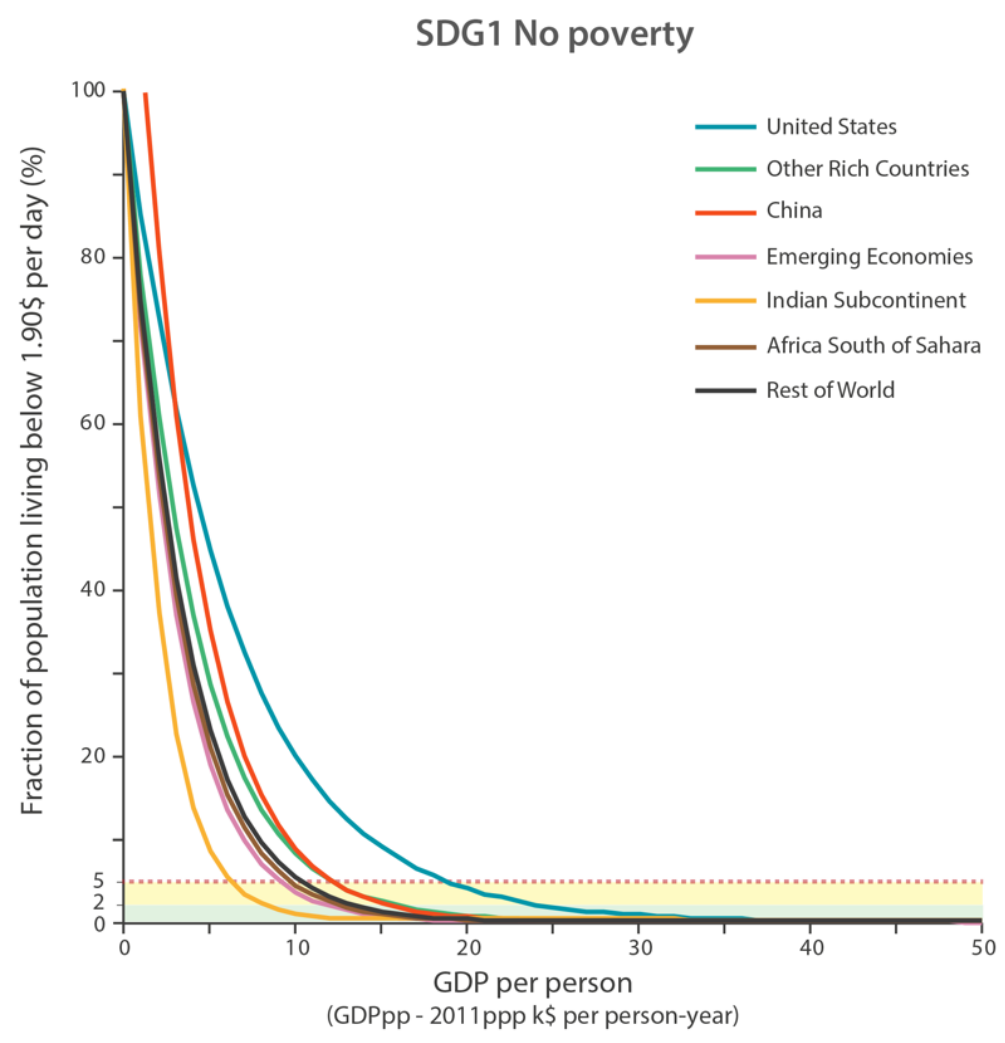

Figure 2: Functions for SDG1 No poverty.
By analyzing the Chinese data, we deemed the functional formula to project unreasonable high levels of poverty and adjusted the formula to:

$$
y=a * \exp (-x / b)
$$

resulting in an a value of 140 . The resulting functions are plotted in Figure 2. Figure 3 portrays the development when we run the model in Scenario 1 to 2050. Notice that Figure 1 and Figure 2 have GDPpp on the horizontal axis, while Figure 3 has time on the horizontal axis.

In the graph one can see, for instance, the rapid decline in Chinese poverty (red line) to reach the "green" zone (<2\%) by

2025. From that year on, China gets a "1" score on this SDG1 (summed up for all regions in the SDG success scores). The regions that are in the yellow area (boundary condition), get " 0.5 " score on this SDG1. Africa South of Sahara gets a 0.5 SDG score on this from 2035 and beyond.

By adding up the number of regions that are in $1,0.5$ or 0 (red) territory, weighted by population, we get the world's SDGs score for any given year. The same procedure has been performed for all SDGs, but we will only present the data and functional formula derived for the rest. 


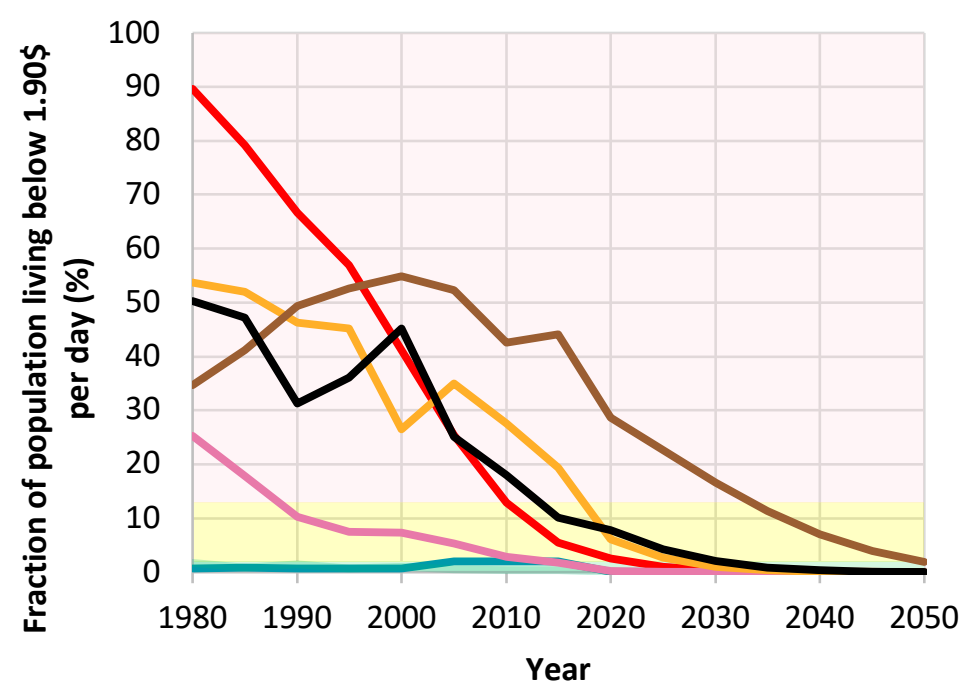

Figure 3: Simulated development on SDG1 in scenario 1.

\section{SDG2 - Zero hunger}

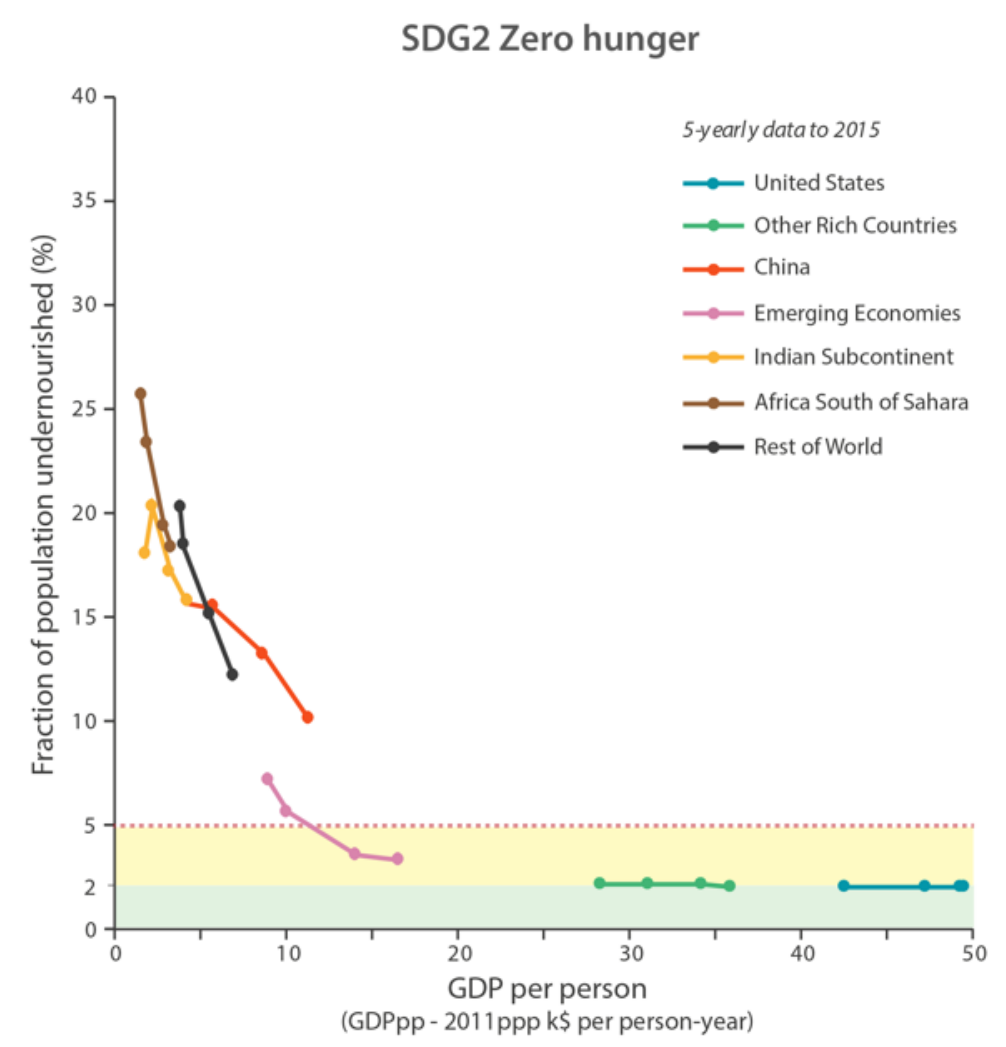

Figure 4: Historical levels of SDG2 Zero hunger.
United States Other Rich Countries

China

Emerging Economies

Indian Subcontinent

Africa South of Sahara

Rest of World

For SDG2 - Zero hunger we use the indicator Fraction of population undernourished. Undernourishment is also used as one of the indicators in the SDG Index and Dashboards Report $2017^{6}$. We have obtained three data points for all regions, for 2000-2015, from the World Bank ${ }^{7}$. The threshold levels of 7 and 15 are based on the SDG Index and Dashboards Report $2017^{8}$. 
Looking at the data on SDG2 portrayed in Figure 4, we found that all regions behave in quite a similar way to SDG1. The data indicates that a function that crosses the $y$-axis at around 35 seems to be reasonable in predicting the future behavior of the variable. The two rich regions United States and Other Rich Countries - have undernourishment levels of around 2.5\% for recent years. We have therefore chosen the functional formula for all regions to be:

$$
y=2.5+32.5 * \exp (-x / b)
$$

\section{SDG2 Zero hunger}

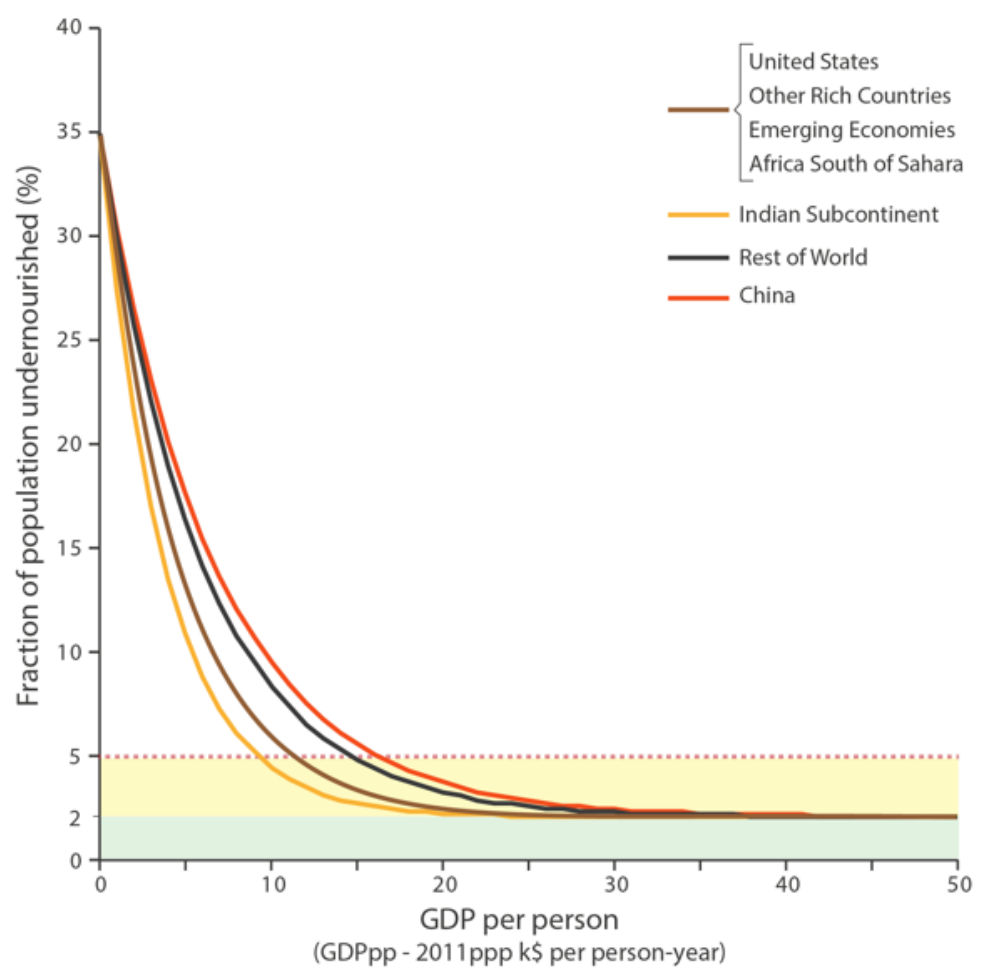

The resulting functions are plotted in Figure 5.

Figure 5:Functions for SDG 2 Zero hunger 


\section{SDG3 - Good health}

For SDG3 - Good health we use the indicator Life expectancy at birth. Data is retrieved from the

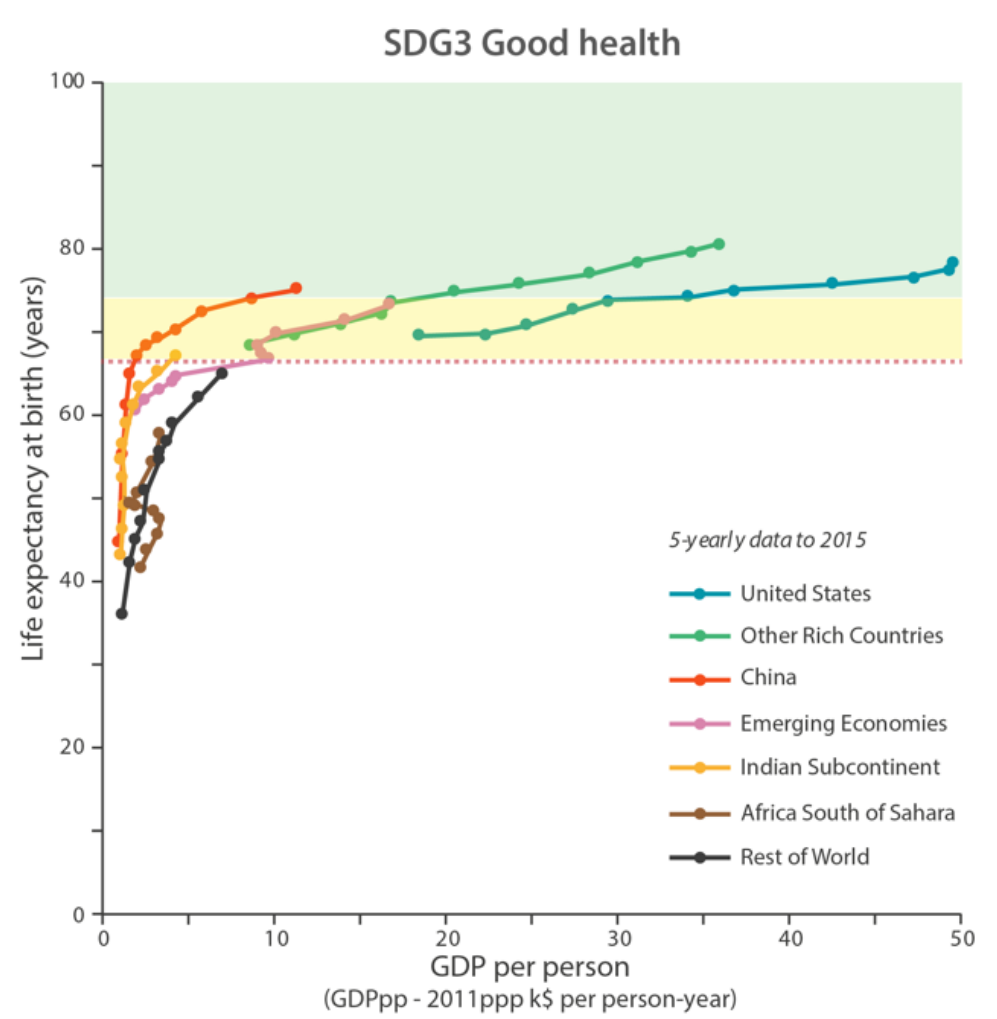

UN Population Statistics from $1965^{9}$ and portrayed in Figure 6. The SDG Index and Dashboard Report $2017^{10}$ includes a similar variable, Healthy life expectancy at birth. We found data availability for healthy life expectancy not as good as for life expectancy. Our threshold values of 70 and 75 years are based on SDG Index and Dashboards Report 2017 and the average difference between data for Life expectancy and Healthy life expectancy for different countries.

For SDG3 we assume both a GDP per capita effect and a technology effect. We have therefore used a function with two parts. The functional formula used:

Figure 6: Historical levels of SDG3 Good health

$y=(70+0.18 *($ years since 1965$)) *\left(1-c^{*} E X P(-X / d)\right)$

The first part of the equation:

$(70+0.18 *($ time -1965$))$

represents the maximum life expectancy and depends on technological advancement, assumed to have a linear effect per year on life expectancy. Parameters $a$ and $b$ where parameterized using all five-year regional data for all countries 1965 to 2015. The $c$ and $d$ parameters were derived by regressing all data points for which life expectancy is higher than 60 years, to prevent the strong catching-up effect at low levels of life expectancy affecting our long-term forecasts.

As no data point is above 60 years for Africa South of Sahara, the same parameter values as for Rest of World are used. The resulting function is plotted for 2015 and displayed in Figure 7. 
This is this is a non-peer reviewed preprint submitted to EarthArXiv.

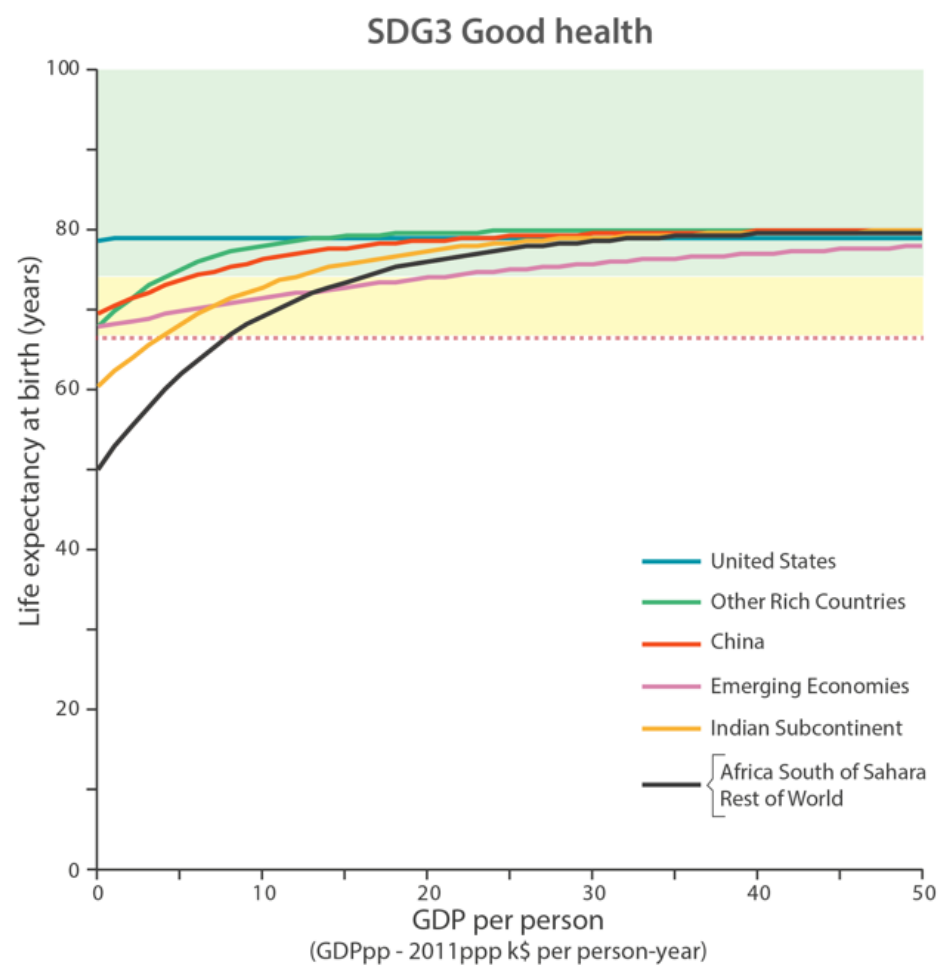

Figure 7: Functions for SDG3 Good health, excluding the technological advance that is part of the full equation, see text.

SDG4-Quality education 


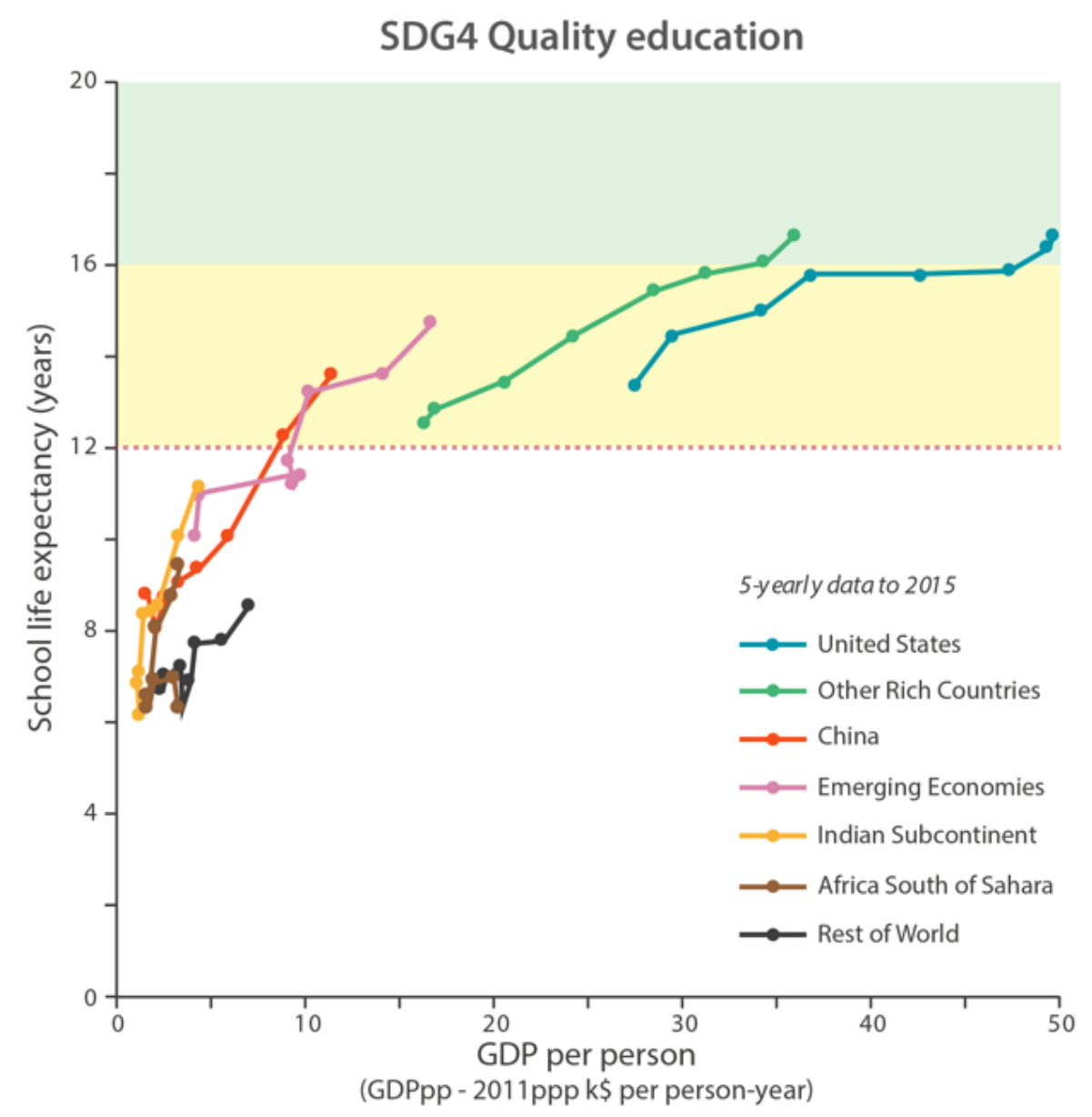

Figure 8

For SDG4 - Quality education we use the indicator School life expectancy, primary to tertiary, both sexes as our indicator. School life expectancy is included in the calculations of the Human Development Reports ${ }^{11}$ and the SDG Index and Dashboards Report $2017^{12}$. The threshold levels of 10 and 12 are consistent with the SDG Index and Dashboards Report 2017. It also corresponds well with the explicit mentioning of secondary education in the Agenda 2030 resolution ${ }^{13}$. We retrieved the data from the World Bank ${ }^{14}$ for 1980-2015 for all world regions.

Looking at our data on SDG4 we found that all regions behave in quite a similar ways. The data indicates that a function that crosses the $y$-axis at around six seems to be reasonable in simulating future behavior of the development. It also seems reasonable to believe that education will not grow forever but may saturate at a level of around 18 years. 
This is this is a non-peer reviewed preprint submitted to EarthArXiv.

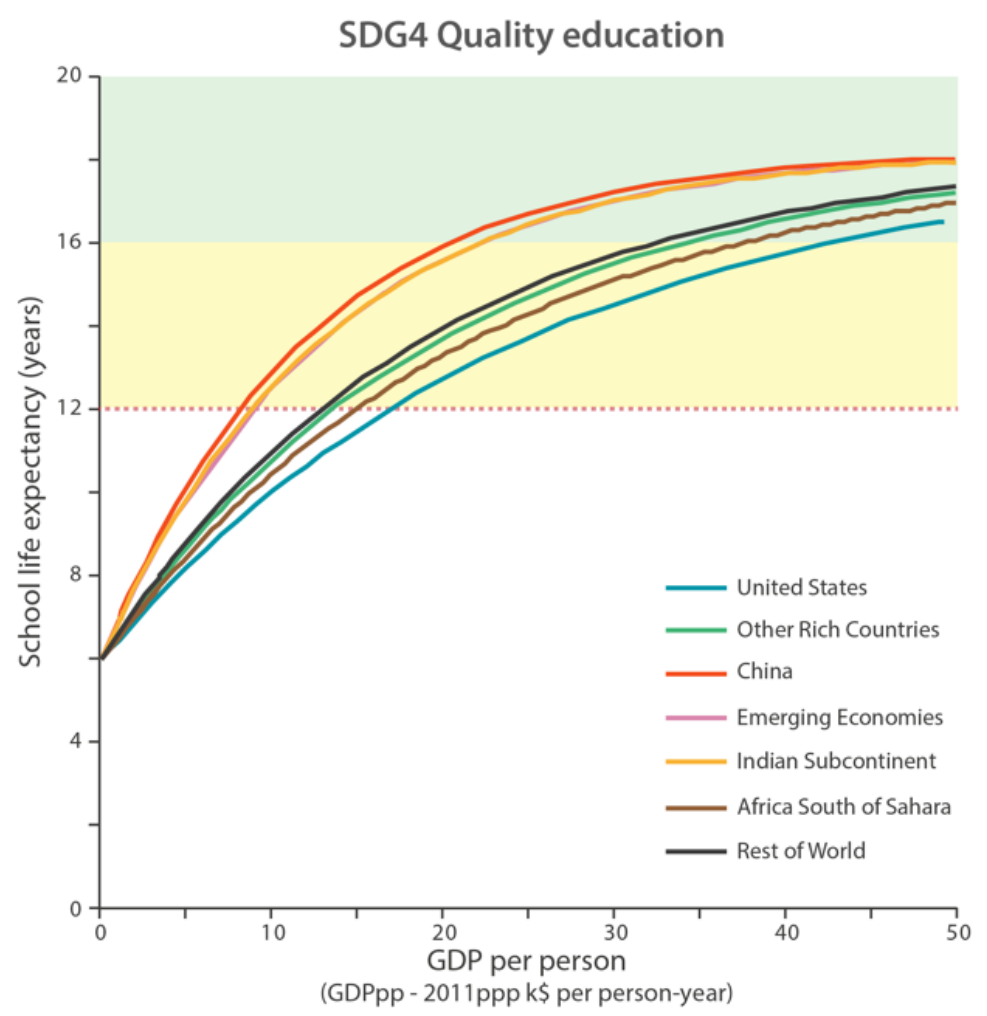

Figure 9

We have therefore chosen the following functional formula for all regions:

$$
y=18-12 * \exp (-x / a)
$$

$a$ was adjusted for the Indian Subcontinent to the same value as for Emerging Economies as we found the value retrieved from the regression unreasonably low.

We also adjusted $a$ for Rest of World as the data points for this region were so low (just above six) that the $a$ value retrieved from the regression would give unreasonably low predictions for the region's future development. 


\section{SDG5 - Gender equality}

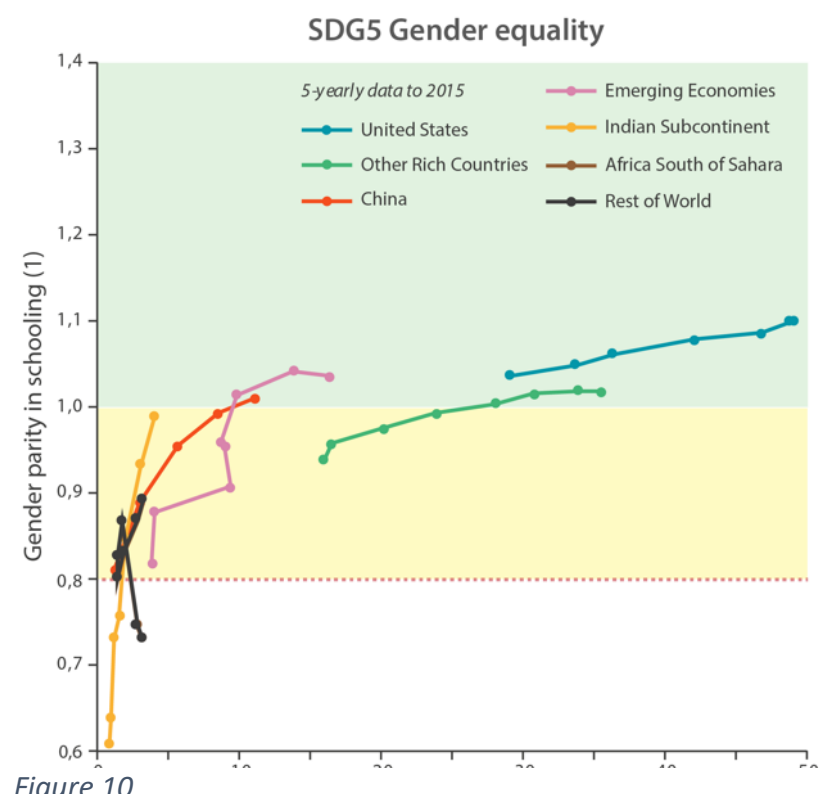

Figure 10

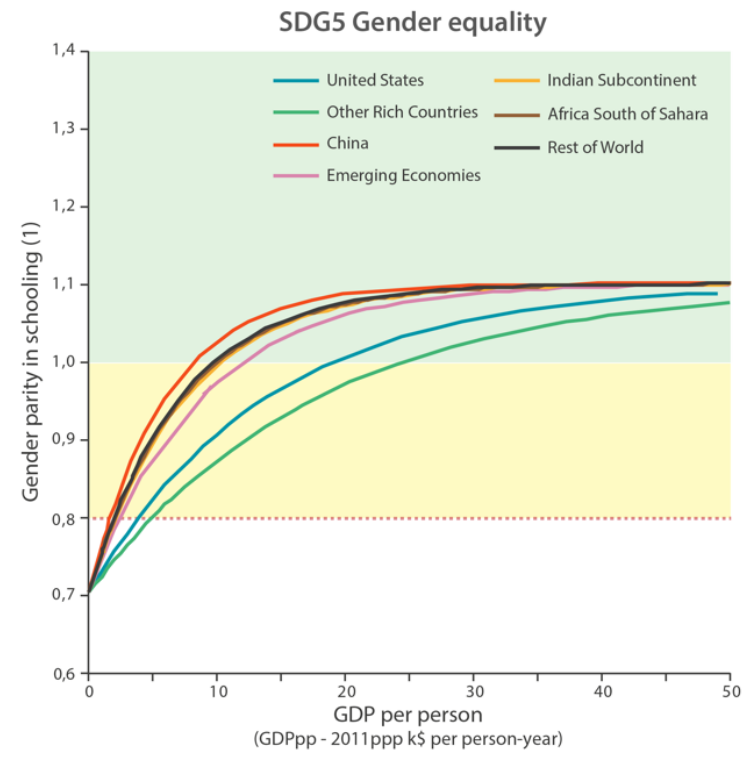

Figure 11
For SDG5 - Gender equality we use School life expectancy, primary to tertiary, gender parity index (GPI) as our indicator. The data was retrieved from the World Bank DataBank ${ }^{15}$ for $1980-$ 2015 for all world regions except United States (1985-2015) and Rest of World (1995-2015). Note that we use the indicator expected years of schooling and not years of schooling for both SDG5 and SDG4. Gender parity of expected years of schooling is the expected years of schooling for women, divided by the expected years of schooling for men. A value of 1 indicates that both men and women have the same expected years of schooling, a value below 1 indicates that men have higher expected years of schooling and a value above 1 that women have higher expected years of schooling.

The SDG Index and Dashboards Report 2017 includes the similar variable Female years of schooling (\% male) and suggests the threshold values of $75 \%$ and $98 \%$ (corresponding to the gender parity index of 0.75 and 0.98 respectively). We use 0.80 and 0.95 . Looking at the data, it seems like the gender parity index grows above 1 for high levels of GDPpp. Also, the data indicates that a function that crosses the $y$-axis at around 0.7 seems to be reasonable in predicting the future behavior. We therefore chose the following functional formula for all regions:

$$
y=1.1-0.4 * \exp (-x / a)
$$

The resulting functions are plotted in Figure 11.

\section{SDG6 - Safe water}

For SDG6 - Safe water we use People using at least basic drinking water services (\% of population) as our indicator. The data was retrieved from the World Bank ${ }^{16}$ for $2000-2015$ for all regions except United States and Rest of World (both 2005-2015), plotted in Figure 12. The SDG Index and Dashboards Report 2017 includes the similar indicator: Access to improved 
water. We use the threshold values that the SDG Index and Dashboards Report 2017 suggests for this indicator, $80 \%$ and $98 \%$.

We have used the functional formula

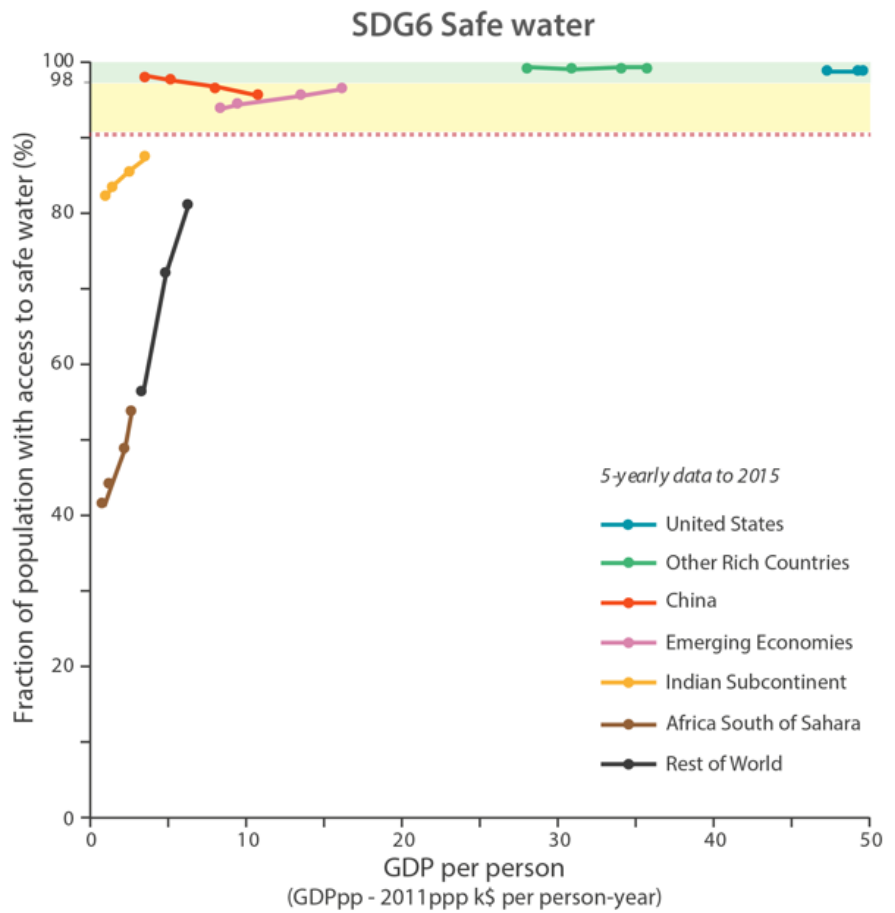

Figure 12

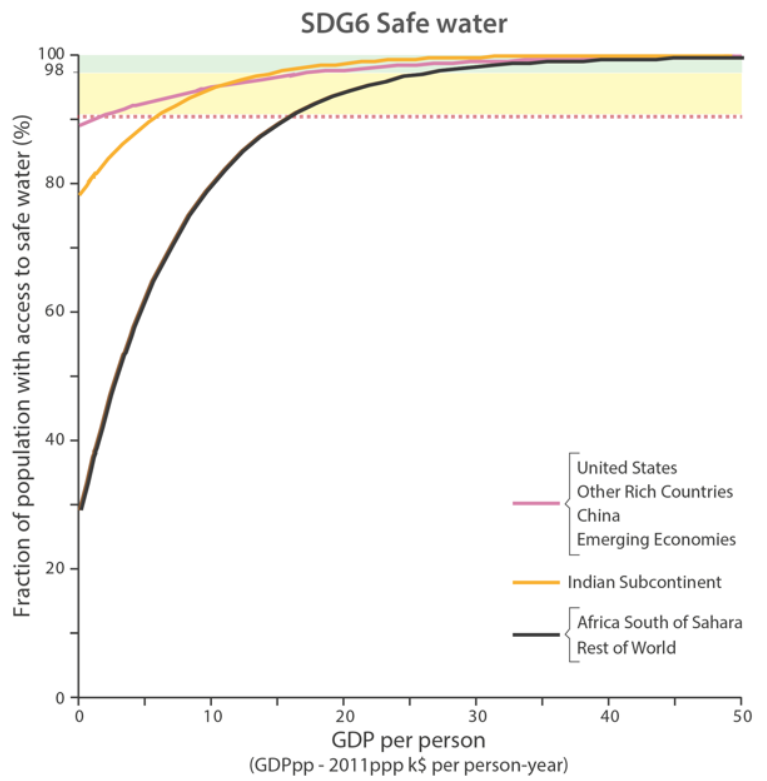

$$
y=100-a * \exp (-x / b)
$$

for predicting future values of safewater access.

Because of the poor data availability (especially when it comes to historical levels for the richer regions), we chose to group similar regions. We use the $a$ and $b$ values that we retrieved from the regression of Emerging Economies for United States, Other Rich Countries and China as well. Also, we used the same parameters for Rest of World as we derived from the regression for Africa South of Sahara, as the $a$ value becomes unreasonably low with a regression of Rest of World alone. The resulting functions are portrayed in Figure 13. 


\section{SDG7-Enough energy}

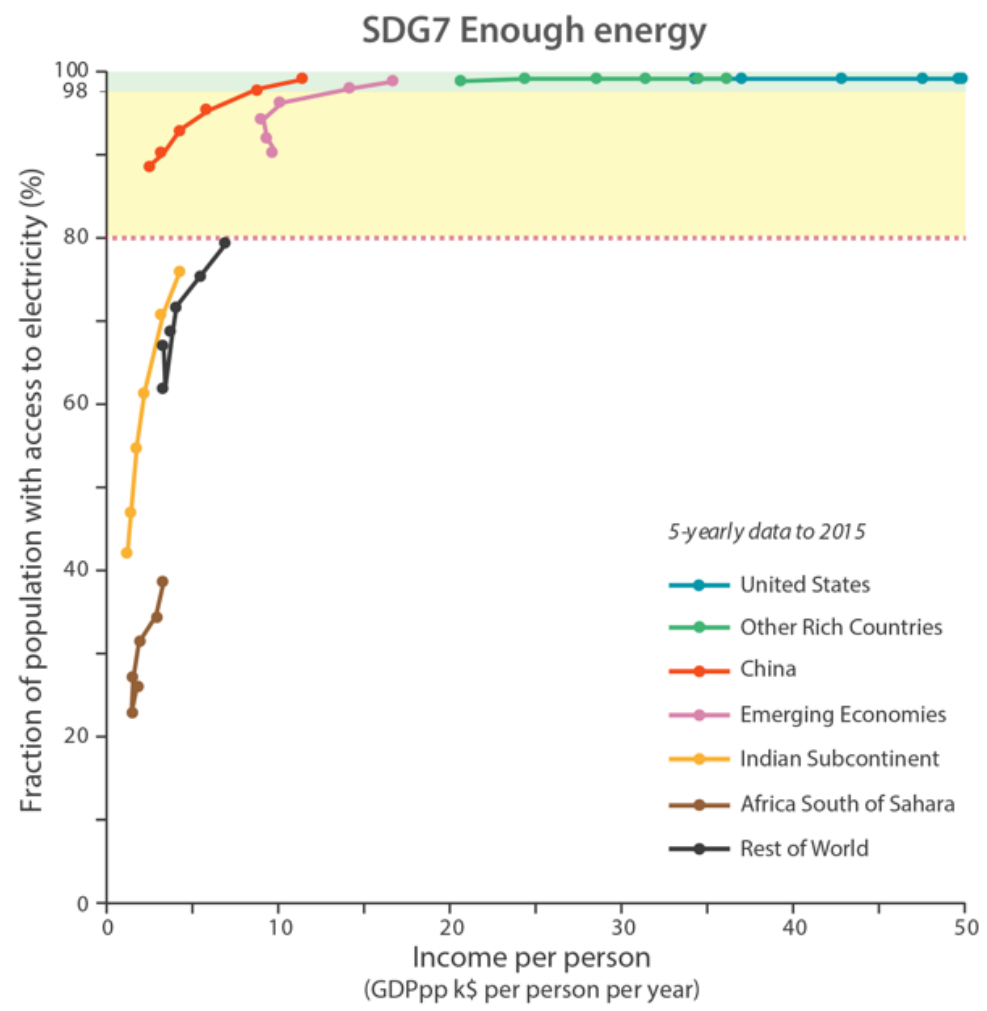

Figure 14

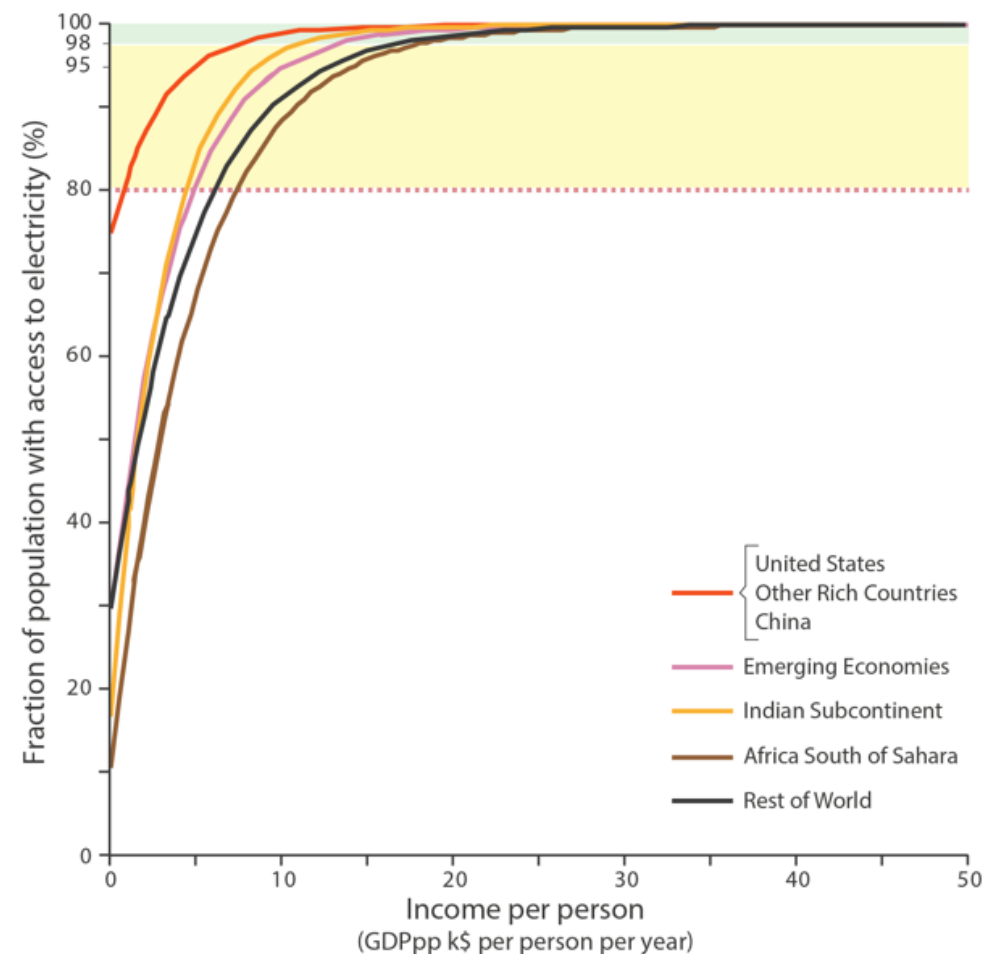

Figure 15
For SDG7 we use the indicator Access to electricity (\% of population) that we retrieved from the World Bank ${ }^{17}$ for 1990 2015 for all our regions, Figure 14. Access to electricity is also included as an indicator for SDG7 in the SDG Index and Dashboards Report 2017. We use the same threshold values as in the SDG Index and Dashboards Report $2017^{18}, 80 \%$ and $98 \%$.

We decided to use the following functional formula:

$y=100-a * \exp (-x / b)$

As all data points for United States and Other Rich Countries are $100 \%$, we use the same parameter values for these regions as for China, while the rest of the parameters were derived through regressions of the respective regions. The resulting functions are plotted in Figure 15. 


\section{SDG8 - Decent jobs}

For SDG8 - Decent jobs we use job-market growth as our indicator. The SDG Index and Dashboards Report $2017^{19}$ suggests various employment indicators and we deem job market growth to be compatible and relevant to these. We assume that job growth is one percentage point less than the rate of change in GDP per person, as we assume that the very long-term productivity increase amounts to this percentage. We calculate the historical rate of change by using GDP values from Penn World Tables in 2011PPP\$ per year ${ }^{20}$ and divide that by historical population from the $U N^{21}$. For the future, we forecast the rate of change in GDP as a function of GDP per person in the previous period using the formula:

$y=a \cdot e^{(-b * x)}-c \cdot e^{(-d \cdot x)}$

We have set $a=9, b=0.07, c=6$ and $d=0.3$

Future population is calculated by forecasting the birth and death rate. For the birth rate, we use the formula:

$y=a+b \cdot e^{\left(-\frac{x}{c}\right)}$

with $a=0.8, b=3$ and $c=5$ and $x$ being the GDP per person in the previous period. This is our global guideline; future values are then adjusted from the previous actual data point with an adjustment time of 20 years. The death rate is forecast by:

$\mathrm{y}=a+b \cdot e^{\left(-\frac{x}{c}\right)}$

with $a=0.8, b=1.5$ and $c=2$ This is our global guideline, future values are then adjusted from the previous data point with an adjustment time of 30 years. Since our formula is trained on data from a time period where the age pyramid was indeed a pyramid, we introduce an aging multiplier on the death rate to represent the changing of the shape of the pyramid that is not yet in the data. This multiplier is:

$\mathrm{y}=\mathrm{a} \cdot \mathrm{e}^{(\mathrm{t}-2015)}$

where $a$ is calculated as the annual rate of change in the fraction of the population 65 and older between 1995 and 2015. The resulting job-market growth is portrayed in Figure 16 together with the historical data. In the Figure 16 we use moving averages for the historical data to smooth the function. 
This is this is a non-peer reviewed preprint submitted to EarthArXiv.

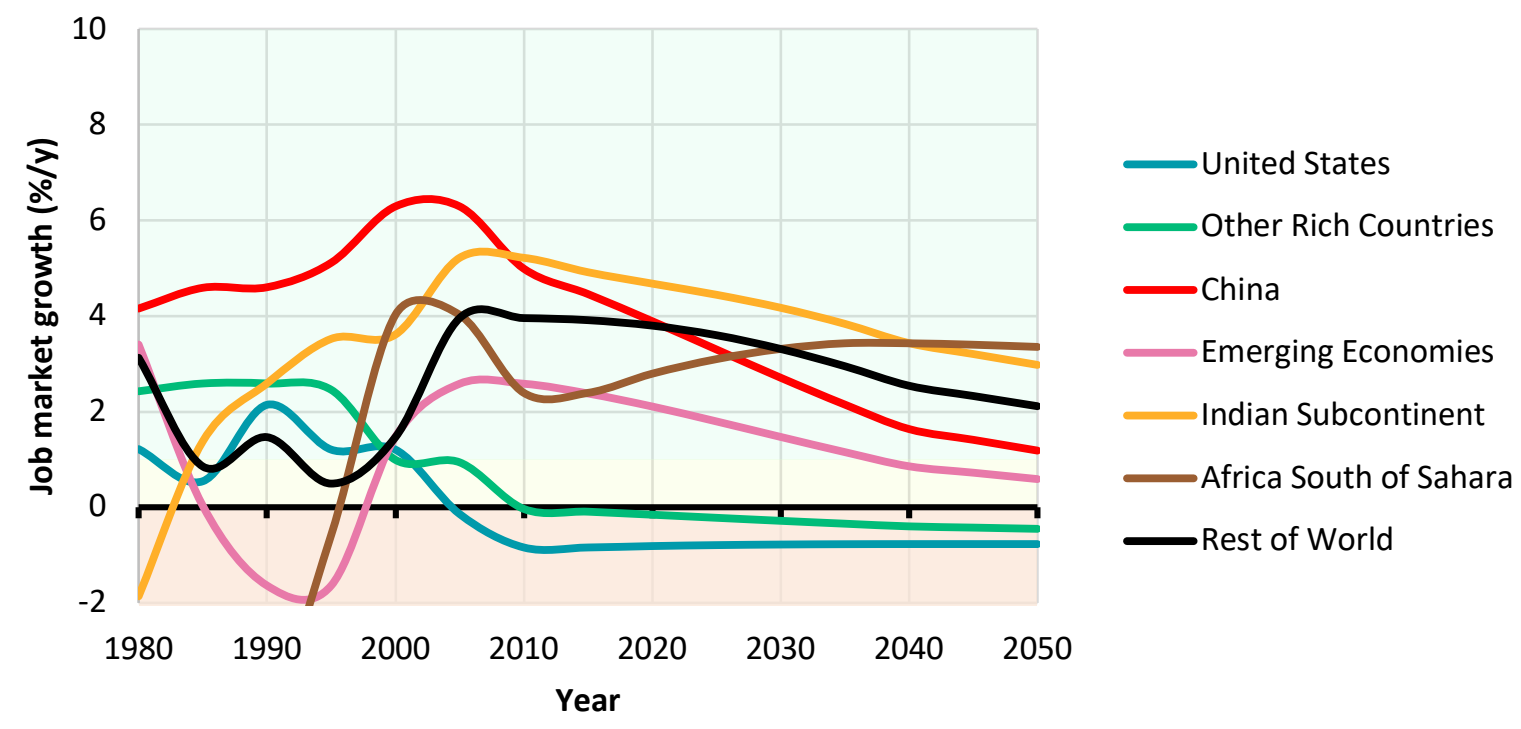

Figure 16

We have chosen the target value of $1 \%$ increase and the halfway target 0 (see green and yellow areas respectively in Figure 16). 


\section{SDG9 - Industrial output}

For SDG9 - Industrial output we use the indicator GDP per person in manufacturing and construction measured in $\mathrm{k} \$ \mathbf{p}$ person-year. We have calculated the historical values from using GDP and fractions of GDP in the primary, secondary and tertiary sectors (see SDG8 above for source). Data on the size of the sectors (as \% of GDP) is retrieved from the World Bank ${ }^{22}$. For the future values we forecast the rate of change in GDP as a function of GDP per person in the previous period using the formula:

$y=a \cdot e^{(-\mathrm{b} * \mathrm{x}}-c \cdot e^{(-d * x)}$

We set $a=9, b=0.07, c=6$ and $d=0.3$. We forecast future shares of agriculture by

$\mathrm{y}=a+b \cdot e^{\left(-\frac{x}{c}\right)}$

with $\mathrm{a}=1, \mathrm{~b}=37$ and $\mathrm{c}=5$ and $\mathrm{x}$ being the GDP per person in the previous period. This is our global guide; actual values are then adjusted to the previous data point with an adjustment time of 20 years. We forecast future shares of services by:

$$
y=a+b \cdot e^{\left(-\frac{x}{c}\right)}+\left(1-e^{\left(-\frac{x}{d}\right)}\right)
$$

with $a=15, b=60, c=1$ and $d=15$ and $x$ being the GDP per person in the previous period. This is our global guide; actual values are then adjusted to the previous data point with an adjustment time of 20 years. The share in industry is:

$y=1$ - share in agriculture - share in services

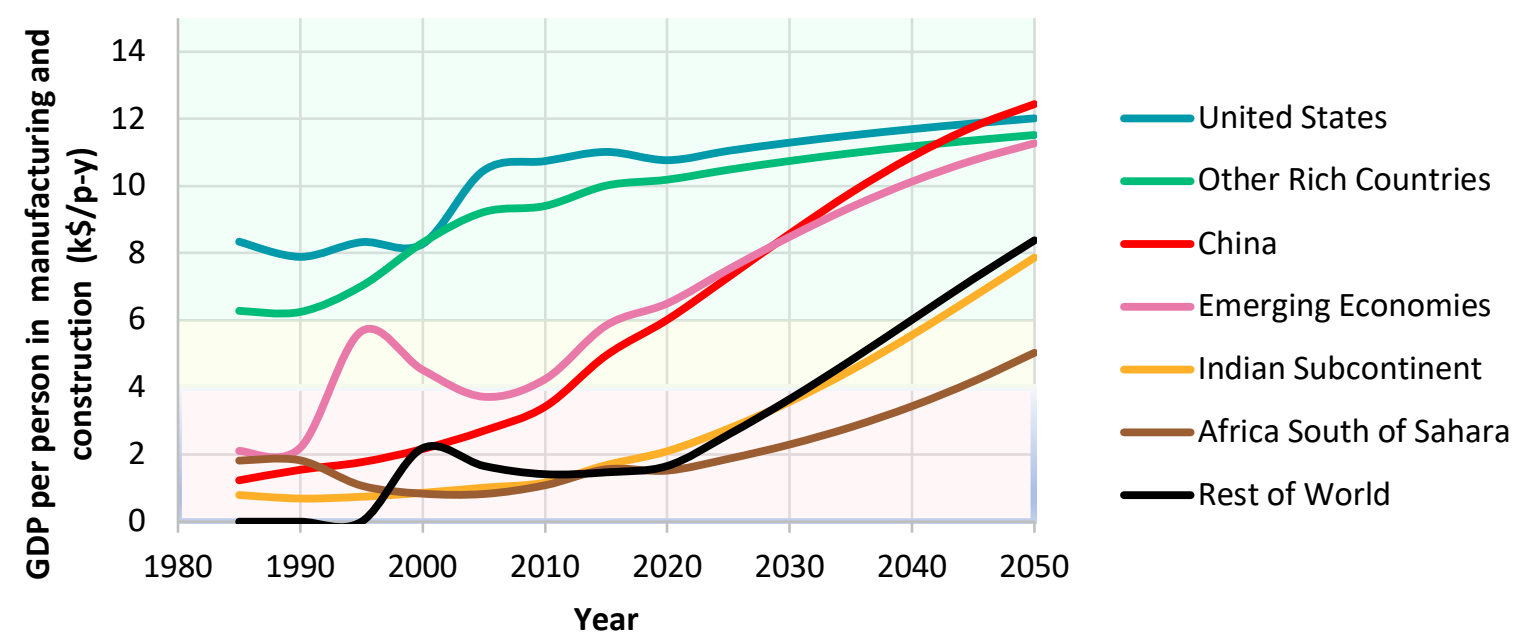

Figure 17 
We have chosen the target values of above $6 \mathrm{k} \$ /$ person-year and set the halfway target at 4 $\mathrm{k} \$ /$ person-year. The resulting behavior of Scenario 1 of the different regions is portrayed in Figure 17 together with the historical data.

\section{SDG 10 - Reduced inequality}

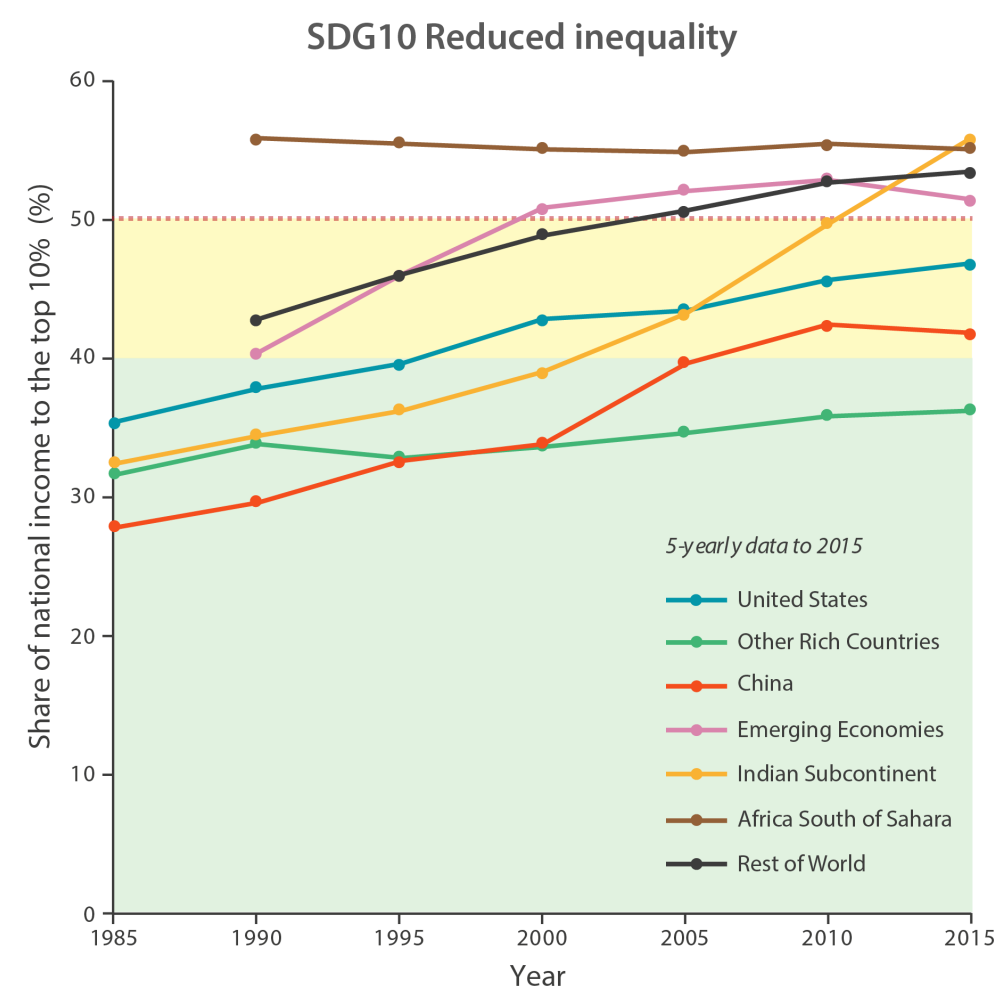

Figure 18
As our indicator for inequality, we use the share of incomes of the top $10 \%$ of the population. The SDG Index and Dashboards Report $2017^{23}$ uses the Palma Ratio which includes the top $10 \%$ (and the bottom $40 \%$ ) of incomes. History is calculated from the World Inequality Database, the percentage of annual pre-tax national income accruing to the top $10 \%$ income earners ${ }^{24}$. World Inequality Database includes data from 1980 for some of the regions, and 1990 for others. We apply their regional differences to derive reasonable values for our regions. We forecast the future manually (ie. exogenously), portrayed in Figure 18 


\section{SDG11-Clean cities}

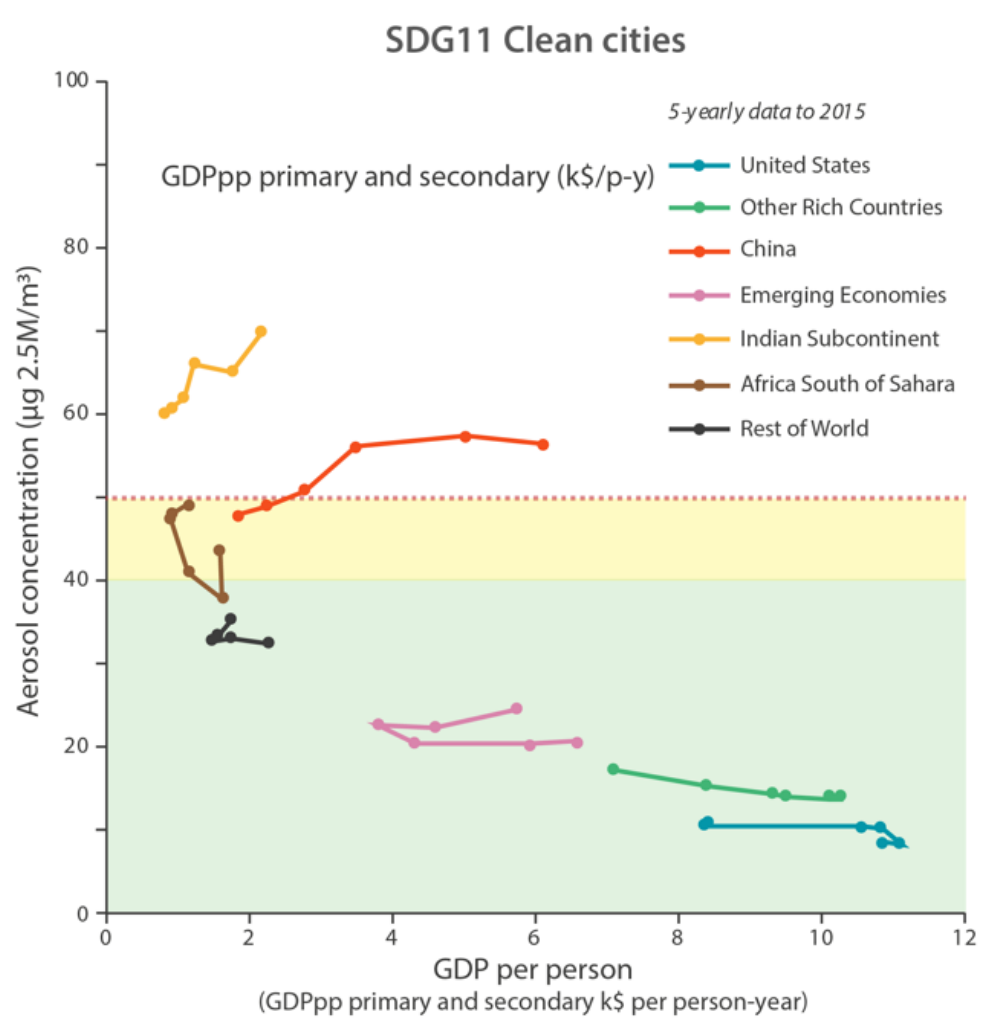

Figure 19

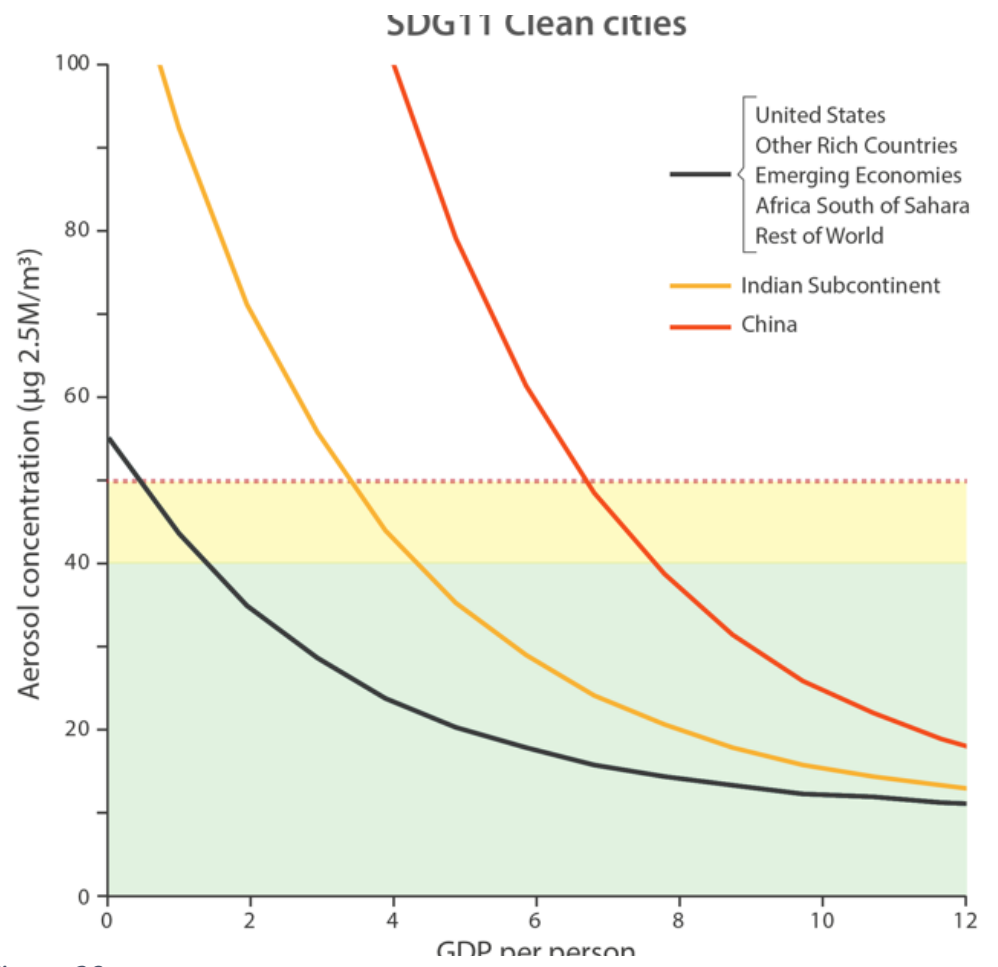

Figure 20
For SDG11 - Clean cities we use the indicator PM2.5 air pollution, mean annual exposure (micrograms per cubic metre) which is the "average level of exposure of a nation's population to concentrations of suspended particles measuring less than 2.5 microns in aerodynamic diameter" 25 . The data was retrieved from the World Bank for 1990-2015 for all world regions, and portrayed in Figure 19. The similar variable, PM2.5 in urban areas, is included in the SDG Index and Dashboards Report 2017. We have chosen the threshold levels 10 and 35 based on the World Health Organization's recommendations ${ }^{26}$ and expert judgement of the planetary boundary on aerosols.

There are diverse sources of air pollution. We have assumed that industrial development is the main driver, and we have chosen to plot it against GDP per person in the primary and secondary sectors. Figure SDG11 indicates an overall decline in aerosol concentrations as the GDP per person in the primary and secondary sectors increases, for all regions except China and the Indian Subcontinent. Also, the lowest concentration values of all countries are around five (for Sweden and Australia). Therefore, we use the following functional formula: 
This is this is a non-peer reviewed preprint submitted to EarthArXiv.

$$
y=5+a * \exp (-x / b)
$$

We regressed the data for United States, Other Rich Countries, Emerging Economies, Africa South of Sahara and Rest of World together. We then adjusted the $b$ value so that we got curves close to the latest values for the Indian Subcontinent and China as we judge that the behavioral patterns of these regions will be similar to the rest of the regions. The functions are portrayed in Figure 20.

\section{SDG12 - Responsible consumption}

As indicator for SDG12 - Responsible consumption we use the ecological footprint per person $(\mathrm{gHa} / \mathrm{p})$. The historical values are calculated from the total ecological footprint ${ }^{27}$, divided by population data from the UN (see SDG8 for source). For the future we forecast the rate of change in GDP as a function of GDP per person in the previous period using the formula

$y=a \cdot x \cdot e^{\left(-\frac{(t-2015)}{c}\right)}$

where $\mathrm{a}$ is set regionally, $\mathrm{c}=40$ and $\mathrm{x}$ is the GDP per person in the agricultural and industrial sector. Values are for a range from 0.5 to 1.0. This is a proportion between $\mathrm{x}$ and $\mathrm{y}$ controlled by the slope a, modified with a rate of technological progress.

Historical values together with the forecast for Scenario 1 are portrayed in Figure 21.

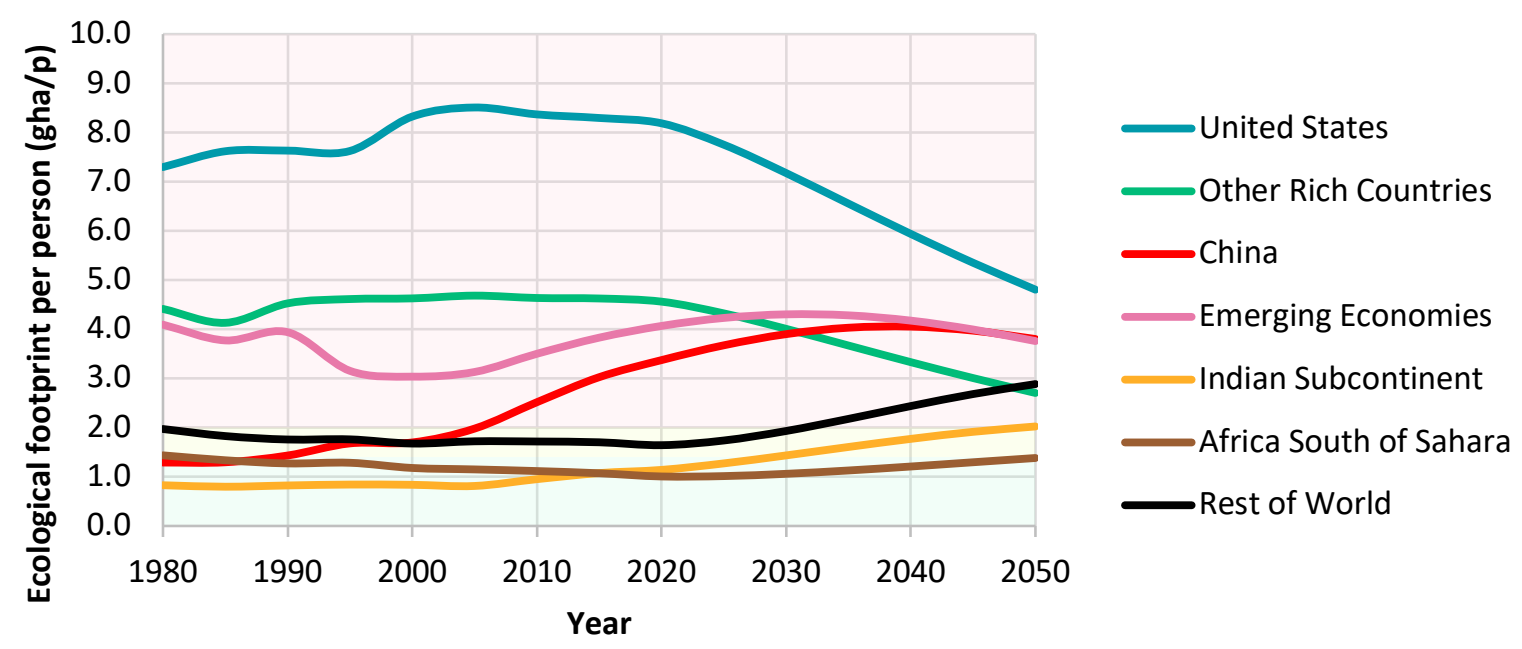

Figure 21

\section{SDG13 - Climate action}

We measure SDG13 - Climate action in global mean temperatures as temperature rise in Celsius degrees above 1850 levels. This is a global indicator, which means that it is the same for all 
regions. History is given by the National Centers for Environmental Information ${ }^{28}$. The raw data is the anomaly to the base "the 20th century". For the future forecast we use ESCIMO, a climate-change model described and fully available here: http://www.2052.info/ESCIMO/To generate the forecast we drive the model with assumptions about greenhouse-gas emissions. See the Planetary Boundary on Climate Change for data and the forecast for Scenario 1. We use the same threshold value as for the planetary boundary, 1 degree and 1.5 degrees.

\section{SDG14 - Life below water}

As an indicator for SDG14 - Life below water we use acidity of ocean surface water $(p H)$. It is a global indicator, which means that it is the same for all regions. This indicator is also the same as the one used for Planetary Boundary Ocean Acidification. Historical data is from the WHOI Hawaii Ocean Time-series Station ${ }^{29}$ and the Bermuda Institute of Ocean Science ${ }^{30}$

For the future forecast we use ESCIMO, a climate-change model described and fully available here: http://www.2052.info/ESCIMO/To generate the forecast we drive the model with assumptions about greenhouse-gas emissions. Also, we use the same thresholds as the safe territory and high-risk zone for the planetary boundary, using above $\mathrm{pH} 8.15$ as target and above 8.10 as a halfway target.

\section{SDG15 - Life on land}

As our indicator for SDG15 - Life on land we use old-growth-forest area measured in $\mathrm{Mkm}^{2}$. It is a global indicator which means that it is the same for all regions. This indicator is also the same as the one used for Planetary Boundary Forest Degradation. Historical data is retrieved from the FAO's Forest Resource Assessment, various years ${ }^{31}$. For the future forecast we use ESCIMO, a climate-change model described and fully available here: http://www.2052.info/ESCIMO/ To generate the forecast we drive the model with assumptions about greenhouse-gas emissions. Threshold values are set to 17 as target and 25 as the halfway target.

\section{SDG16-Good governance}

For SDG16 - Good governance we use the indicator government spending per person as measured in 2011 PPP US\$ $\$ p-y$. The historical data is calculated from GDP (see SDG8 for source) and fraction of GDP in government spending, also from the Penn World Tables. How we forecast GDP is detailed in the section on SDG8 above. We forecast future shares of government spending by

$$
y=a+b \cdot e^{\left(-\frac{x}{c}\right)}+\left(1-e^{\left(-\frac{x}{d}\right)}\right)
$$

with $a=20, b=10, c=2$ and $d=25$ and $x$ being the GDP per person in the previous period. This is our global guide; actual values are then adjusted to the previous data point with an adjustment time of 20 years. The forecast for Scenario 1 is presented in Figure 22 together with historical data. 


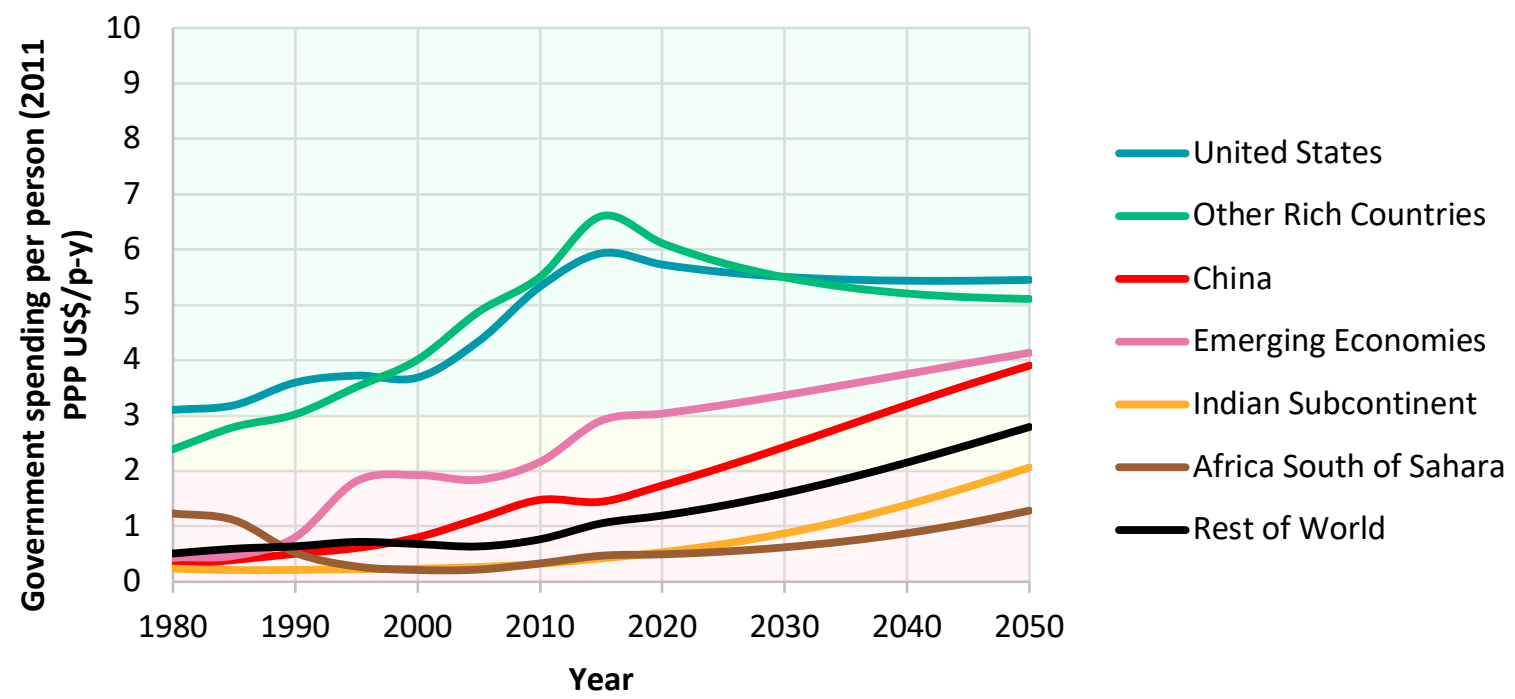

Figure 22

\section{SDG17-More partnership}

For SDG17 - More partnership we use the indicator exports as fraction of GDP (\%). History is calculated from GDP (see SDG8 for source) and fraction of GDP in exports, also from the Penn World Tables. How we forecast GDP is the description for SDG8. We forecast future export fractions manually. Historical data and future forecast is presented in Figure 23.

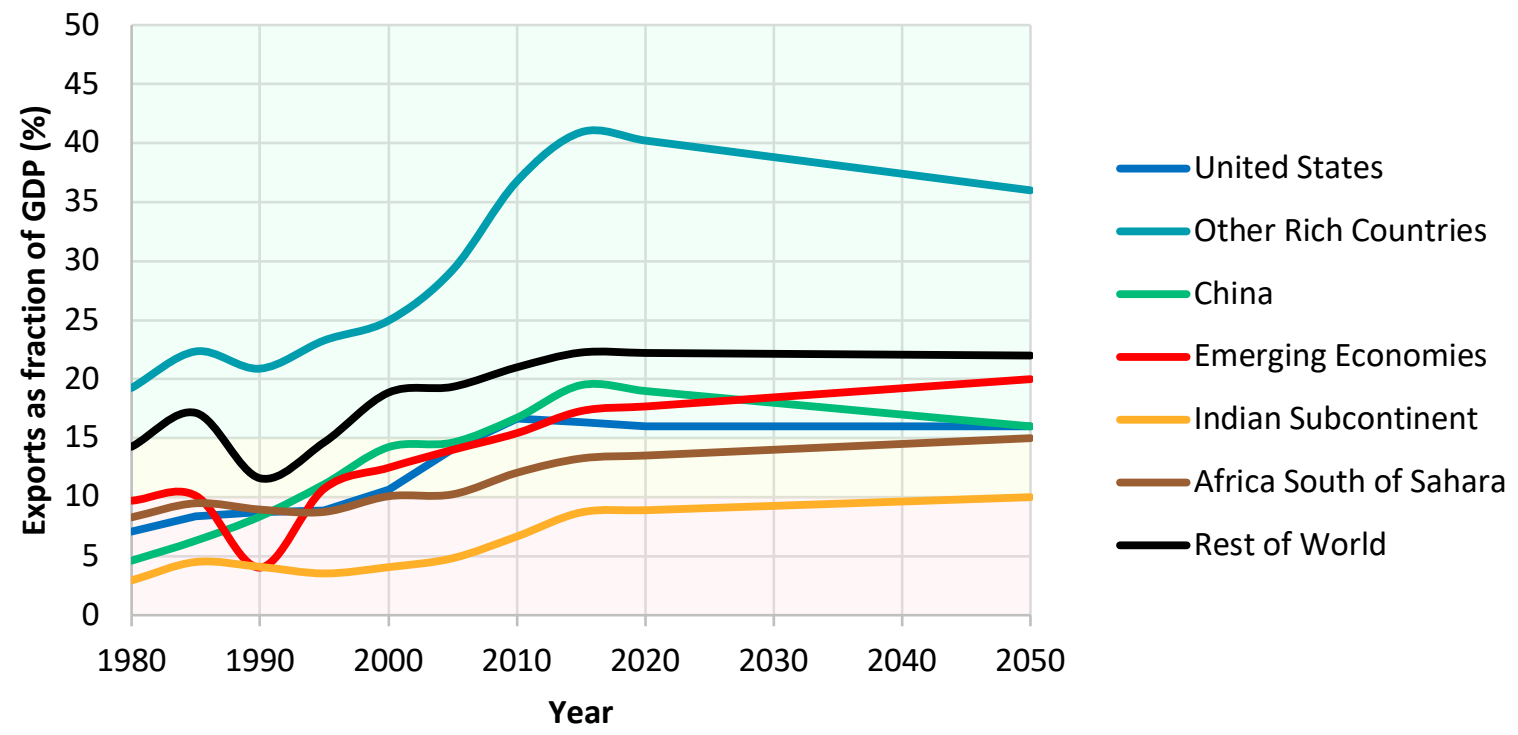

Figure 23 


\section{Planetary boundaries}

We measure the different effects of human activities on the nine planetary boundaries in terms of the production and consumption activities that are included in the Earth3-core module, supported by the environmental system dynamics model ESCIMO (full high-level description, model equations and documentation and input data available at www.2052.info/ESCIMO).

We have used the planetary boundaries processes as presented in Steffen et al. (2015) ${ }^{32}$ and Rockström et al. (2009) ${ }^{33}$. Where possible, we retain their indicators. In some cases, we have had to use other indicators for which historical data are available back to 1980 . For these, we have chosen indicators that have widespread real-world application, especially in policy contexts, and that are sensitive to changes over the time frame to 2050 . In setting the safe and high-risk zones for these indicators, we have focused on the points where scientific assessment coincides with multilateral and international policy concern about large-scale systemic environmental change.

We present the planetary boundaries together with a rationale behind our thresholds and graphs that includes historical development and our forecasted Scenario 1 values.

\section{PB 1 - Global warming}

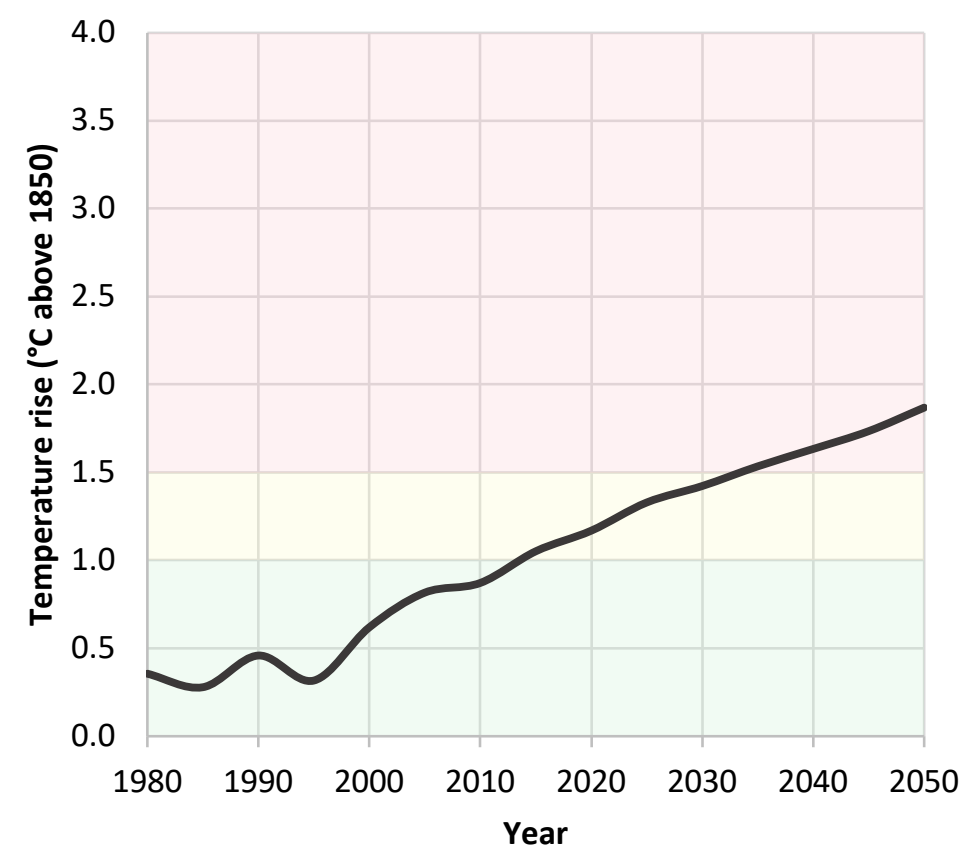

\section{Global warming}

For our analysis of the climatechange planetary boundary, we use temperature rise as the indicator. $\mathrm{ESCIMO}^{34}$ calculates global average temperature rise, and this is the same indicator that we use for SDG13 - Climate action. Global temperature is a good indicator for measuring climate change because it is both intuitive and it is the basis of political negotiations on climate change.

The safe zone is set to below 1 degree Celsius above preindustrial levels. This encompasses the long-term temperature variability of the previous few millennia, during which the world's civilizations established themselves. The

Figure 24

high-risk zone is set above 1.5 degrees Celsius, where there is broad scientific and policy consensus that climate-change risks to societies and ecosystems will be globally severe. Note 
that we run the model until 2050, and a 1.5-degree temperature rise until 2050 may be consistent with a 2-degree increase to 2100. See Figure 24.

\section{PB 2 - Ozone depletion}

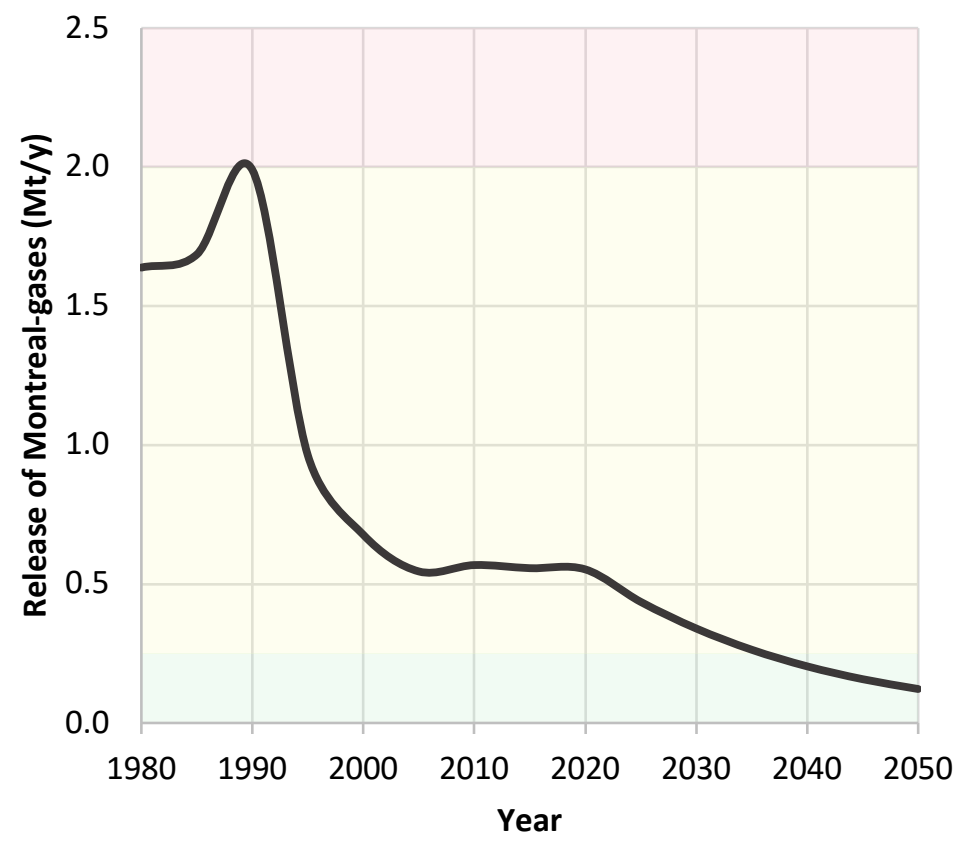

Figure 25

\section{Ozone depletion}

We measure ozone depletion as the release of Montreal gases. This indicator gives a measure of the emissions derived from human activities that drive the growth of the ozone hole. The Montreal gases are powerful greenhouse gases that contain stratospheric ozone-depleting chlorine and bromine atoms. We have set the safe zone to below $0.25 \mathrm{Mt} /$ year, and the high-risk zone above $2 \mathrm{Mt} /$ year corresponding to emission levels driving the emergence and largescale expansion of the ozone hole. For the future we forecast Montreal gas emissions as a function of GDP per person in the previous period using the formula:

$y=a \cdot x^{-b} \cdot e^{\left(-\frac{(t-2015)}{c}\right)}$

where $a=2.2322, b=2.269$ and $c=40 . x$ is the GDP per person. The resulting figure is then multiplied by the total GDP to get the total gases. The exponential term reflects our assumption that Montreal gases will be phased out with a half-life of 40 years (less in scenario 4$)$. See Figure 25. 


\section{PB 3 - Ocean acidification}

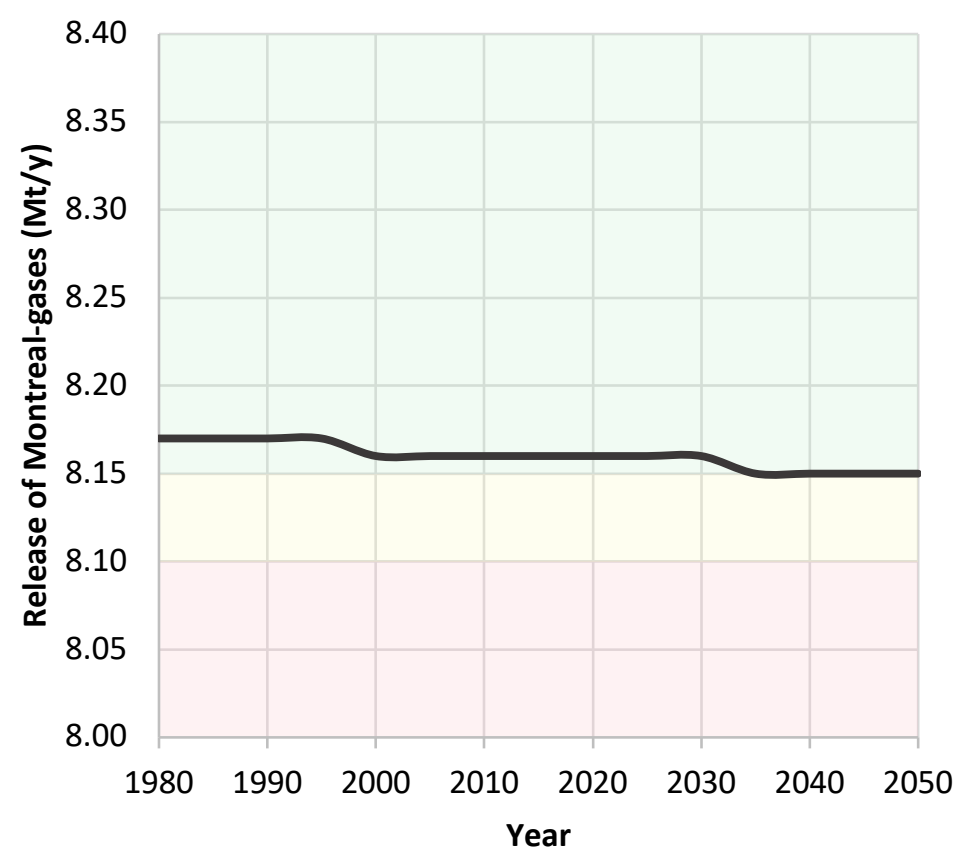

Figure 26

\section{Ocean acidification}

Ocean acidification is the decrease in the $\mathrm{pH}$ value of the oceans, caused when carbon dioxide from the atmosphere dissolves in sea water. Since the industrial revolution, the ocean has absorbed about one-quarter of anthropogenic carbon emissions $^{35}$. The lowered $\mathrm{pH}$ alters the ocean carbon cycle, and has severe impacts on marine organisms, especially corals, plankton and shellfish. We have set the safe zone for ocean acidification as $\mathrm{pH}$ values above 8.15 , corresponding approximately to pre-industrial levels of atmospheric $\mathrm{CO}_{2}$. We set the high-risk zone to $\mathrm{pH}$ values below 8.10 , which is the same as for SDG14. History is from the WHOI Hawaii Ocean

Time-series Station ${ }^{36}$ and the Bermuda Institute of Ocean Science ${ }^{37}$. For the future forecast we use ESCIMO, a climate-change model described and fully available here:

http://www.2052.info/ESCIMO/. The results are portrayed in Figure 26.

\section{PB 4 - Forest degradation}

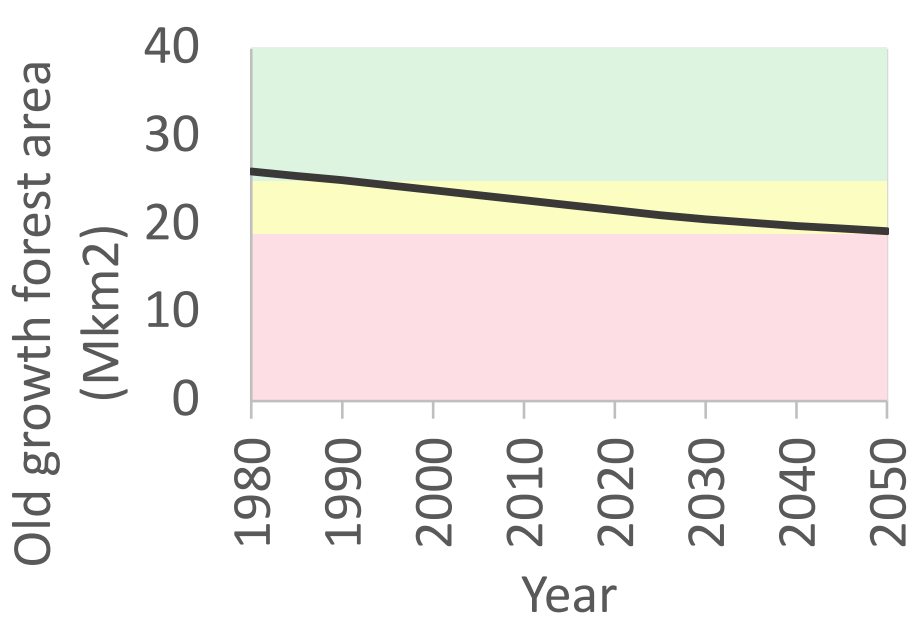

Figure 27 


\section{Forest degradation}

As the indicator for the planetary boundary on land use, we have used old-growth-forest area measured in $\mathrm{Mkm}^{2}$. Old growth forest is especially important in the maintenance of biodiversity, and deforestation also affects the Earth system through changes in the water cycle, $\mathrm{CO}_{2}$-emissions and long-term carbon storage. Tropical forests support at least two thirds of the world's biodiversity ${ }^{38}$. Our safe zone is a forested area above $25 \mathrm{Mkm}^{2}$ and the high-risk zone is below $19 \mathrm{Mkm}^{2}$. History is from the FAO's Forest Resource Assessment, various years ${ }^{39}$. For the future forecast we use ESCIMO, a climate-change model described and fully available here: http://www.2052.info/ESCIMO/.

\section{PB 5 - Nutrient overloading}

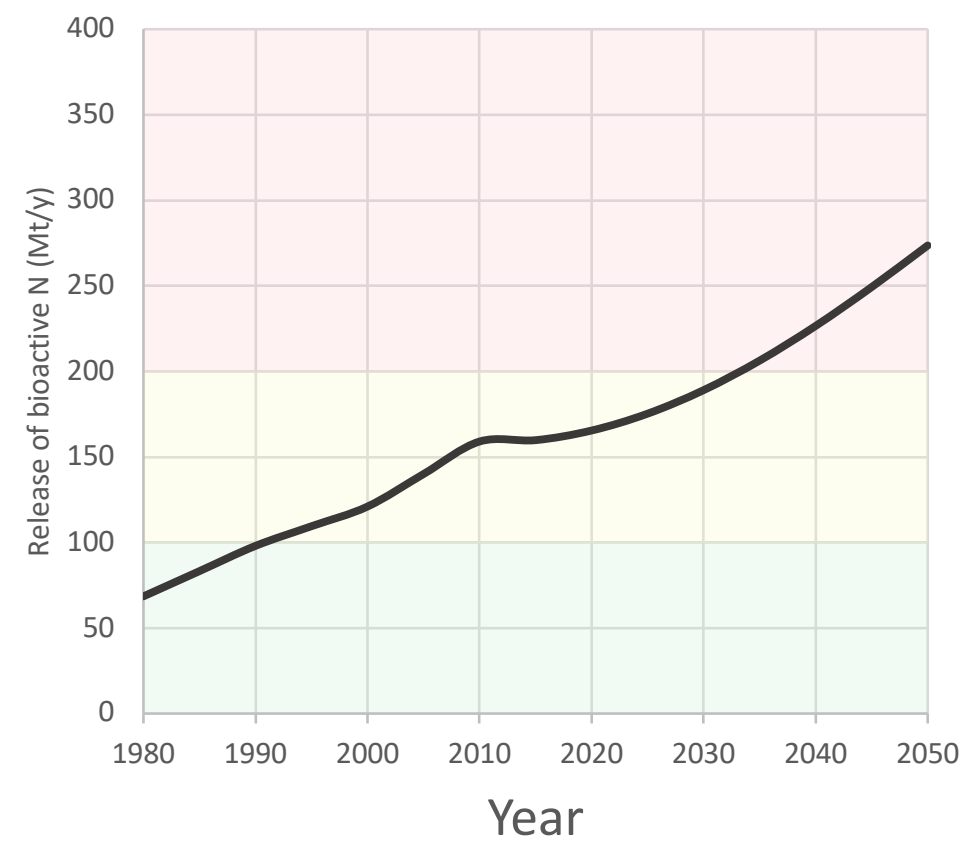

Figure 28

\section{Nutrient overloading}

We measure the change in biogeochemical flows of nutrient elements in terms of the environmental release of bioactive nitrogen from human activities. The overloading of nutrient elements (particularly nitrogen and phosphorus compounds applied as fertilizers) has severe environmental consequences, including losses of water quality, increases in algal blooms and more extensive ecosystem changes. We have set the safe zone of nitrogen release at less than $100 \mathrm{Mt} \mathrm{N} /$ year and the high-risk level at more than $200 \mathrm{Mt} N /$ year, in line with Rockström et al. (2009) and Steffen et al. (2015) values on fixation rate.

For the future we forecast nitrogen flow as a function of GDP per person in the previous period using the formula:

$$
y=(a \cdot x+b) \cdot e^{\left(-\frac{(t-2015)}{c}\right)}
$$

For $\mathrm{N}: \mathrm{a}=1.1704, \mathrm{~b}=52.524$ and $\mathrm{c}=20 . \mathrm{x}$ is the GDP in T\$/y. In the Earth3-core, we have included a similar function calculating release of bioactive phosphorus, but this is not included in this version's calculation of the safety margin. See Figure 28. 


\section{PB 6 - Freshwater overuse}

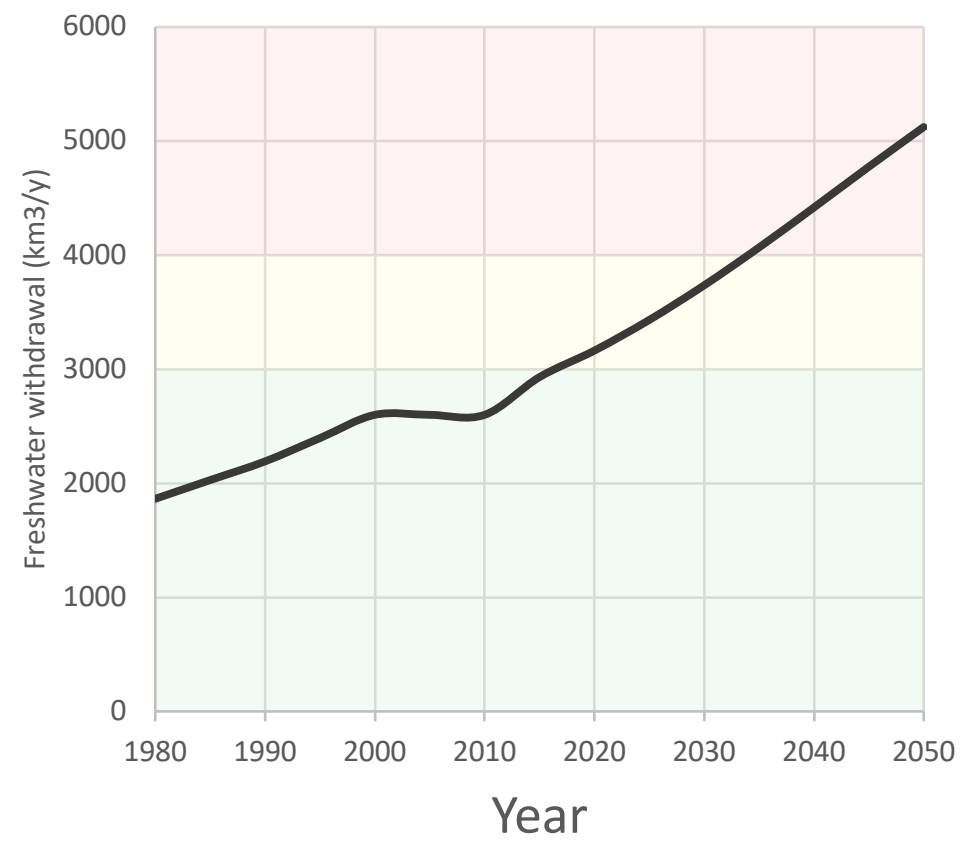

Figure 29
Freshwater overuse

For the planetary boundary on freshwater, the indicator we use is freshwater withdrawal measured in $\mathrm{km}^{2} /$ year. Human pressure on worldwide water resources is becoming increasingly severe. As in Steffen et al. (2015), the high-risk zone is set to freshwater withdrawal above $4000 \mathrm{~km}^{2} /$ year. The safe zone is set to below 3000 $\mathrm{km}^{2} /$ year. For the future we forecast water use as a function of GDP per person in the previous period using the formula:

$y=a \cdot x+b$

where $a=13.972$ and $b=1613.3$ Data is retrieved from Steffen et al. $(2015)^{40}$ and Rockström et al. (2009). ${ }^{41}$ 


\section{PB 7 - Biodiversity loss}

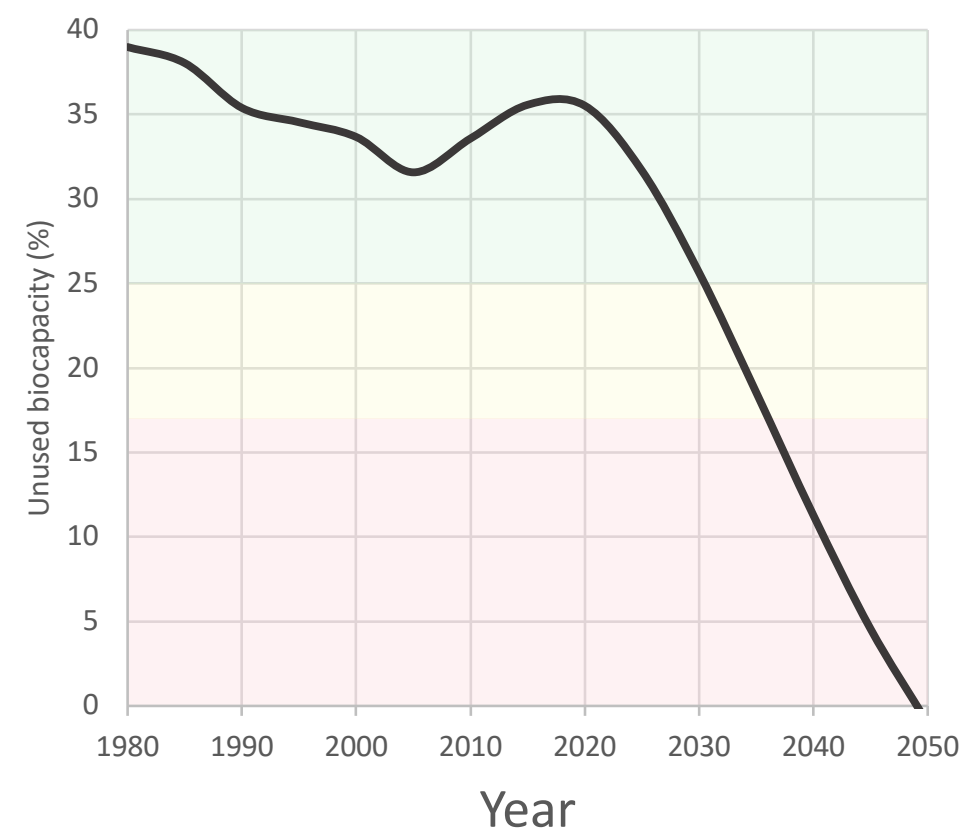

\section{Biodiversity loss}

For the planetary boundary on biodiversity loss we use unused biocapacity as our indicator. The worldwide erosion of biosphere integrity reduces nature's resilience to disturbances and its capacity to contribute to human wellbeing. The biocapacity metric is a departure from the count of extinctions proposed in Rockström et al. (2009). We chose it because it can represent both gains and losses in biosphere integrity on the time frame of our analysis. It is also widely used as part of ecological footprinting by countries, businesses and other groups and individuals. The safe zone is set to above $25 \%$ of the biocapacity and the high-risk zone to below $12 \%$. History is calculated from

Figure 30 data from the Global Footprint Network ${ }^{42}$. From their data we calculate a non-energy footprint
as the difference between their total ecological footprint and their carbon footprint. We divide our non-energy footprint with their biodiversity.

We forecast our non-energy footprint as a function of GDP per person in the previous period using the formula:

$$
y=a \cdot x \cdot \quad\left(\frac{-(t-2015)}{c}\right)
$$

where $\mathrm{a}$ is set regionally, $\mathrm{c}=60$ and $\mathrm{x}$ is the GDP per person in the agricultural and industrial sectors. Values are for a range from 0.12 to 0.3 . This is a proportion between $x$ and $y$ controlled by the slope a, modified with a rate of technological progress. We also assume an adjustment time to the previous data point of 20 years. Finally, we assume a biodiversity loss of $5 \%$ in 2050 over 2015. See Figure 30. 


\section{PB 8 - Air pollution}

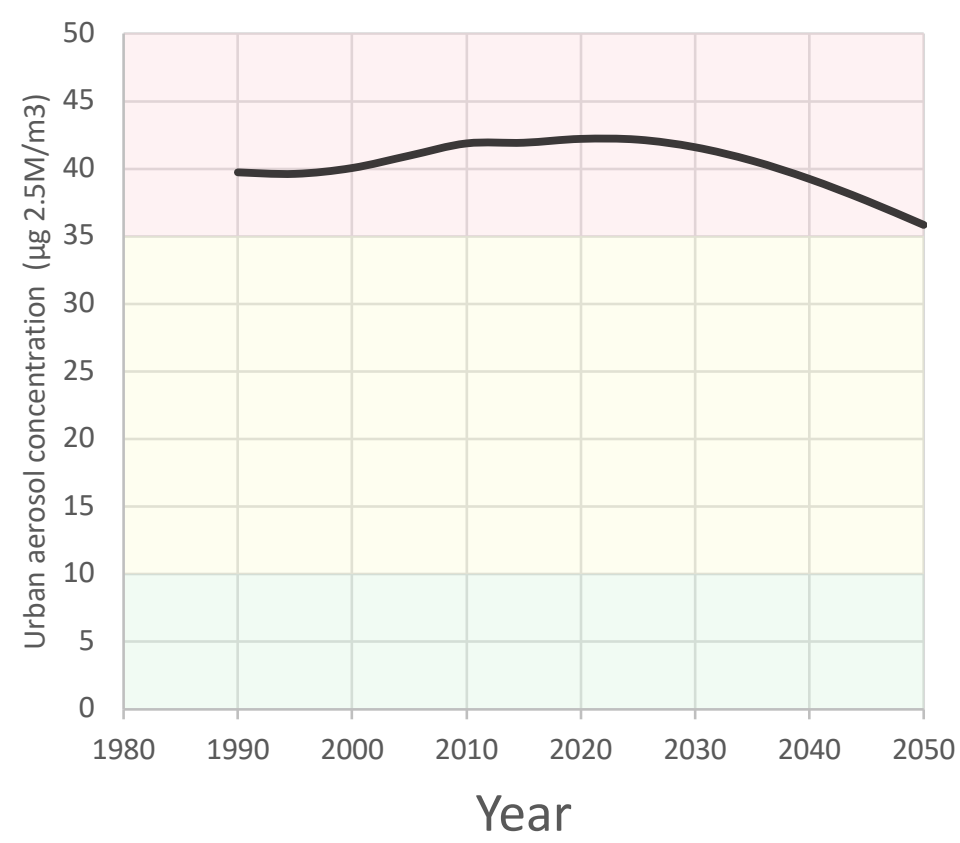

Figure 31

\section{Air pollution}

Our indicator for atmospheric aerosols is the concentration of fine particulate matter in air (PM2.5), measured as $\mu \mathrm{g}$ per $\mathrm{m}^{3}$. This is the same indicator as for SDG11. Fine particles in the atmosphere are a consequence of emissions from transport, industrial processes and agriculture. They have effects on the water cycle, climate and ecosystem health. The safe zone is set to less than $10 \mu \mathrm{g}$ per $\mathrm{m}^{3}$ and the high-risk zone set to above $35 \mu \mathrm{g}$ per $\mathrm{m}^{3}$. Although Steffen et al. (2015) did not provide a globally quantified aerosols boundary, they demonstrated that large-region climate changes associated with intense air pollution are already a cause for concern. For the future we forecast air pollution as a function of GDP per person in the previous period using the formula:

$y=a+b \cdot e^{\left(-\frac{x}{c}\right)}$

where $a=5, b=46$ (100 for the Indian subcontinent) and $c=5$. We also assume an adjustment time to the previous data point of 15 years. The data is retrieved from the World Bank ${ }^{43}$. See Figure 31. 


\section{PB 9 - Toxics contamination}

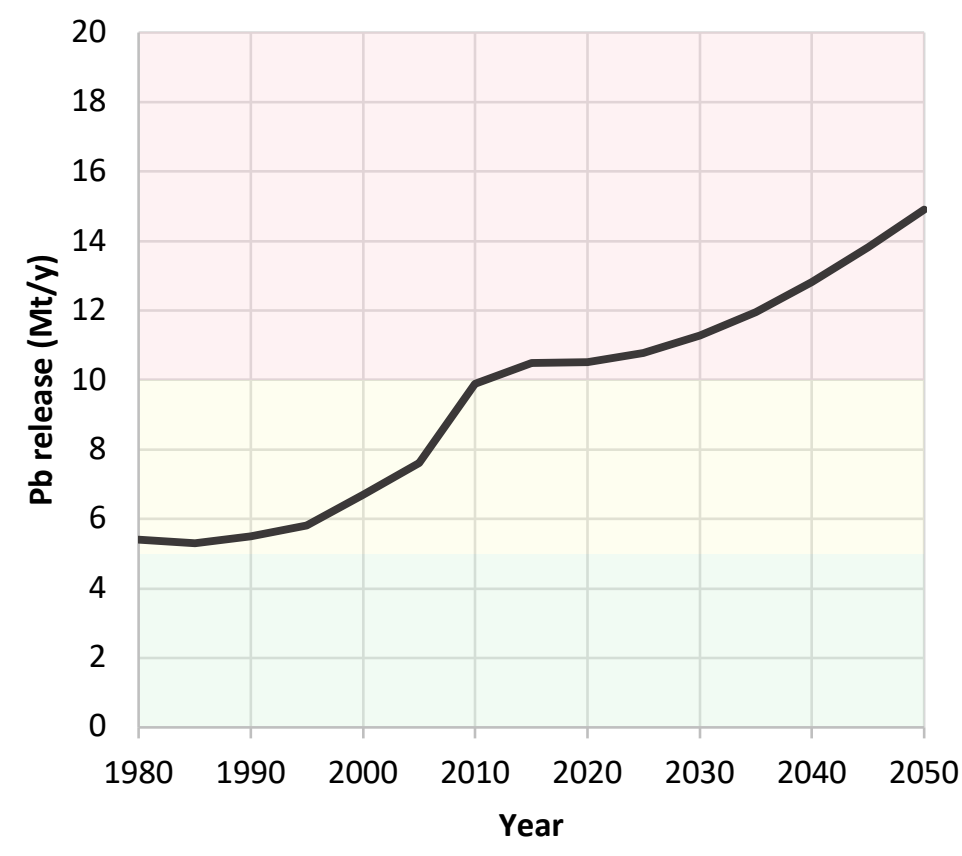

Toxics contamination

There is not a globally quantified novel entities boundary, although Steffen et al. (2015) explain the precautionary rationale, emphasising the longterm persistence and global distribution of harmful substances. We have used the total production of lead (which has the elemental symbol $\mathrm{Pb}$ ) as an indicator for the planetary boundary on novel entities. Historical data trace the drivers, impacts and societal responses to lead emissions, linked to its longterm use as a vehicle fuel additive. The safe zone of $\mathrm{Pb}$ production is set to below 5 Mt/year and the high-risk zone above $10 \mathrm{Mt} /$ year.

Figure 32

For the future we forecast $\mathrm{Pb}$ production as a function of GDP per person in the previous period using the formula:

$\mathrm{y}=(a \cdot x+b) \cdot e^{\left(-\frac{(t-2015)}{c}\right)}$

where $\mathrm{a}=0.0544, \mathrm{~b}=4.4918$ and $\mathrm{c}=20 \mathrm{x}$ is the GDP in T\$/y. The data for $\mathrm{Pb}$ production is retrieved from the International Lead Association ${ }^{44}$. We measure total metal production. However, in future development of the model it may be useful to differentiate between mine production of lead and recycled lead. See Figure 32. 
This is this is a non-peer reviewed preprint submitted to EarthArXiv.

\section{Specification of the seven regions}

We have divided the world's countries into economic regions. The source of the national economic data we have used is the Penn World Tables, version $9{ }^{45}$ available for download at www.ggdc.net/pwt. All GDP data are in 2011 PPP \$, in the table below 2011 PPP G\$/y. (1 G\$ = 1 billion $\$=1000$ million $\$$.) Population data is from UN Population Division: https://esa.un.org/unpd/wpp/DataQuery/

We have used seven regions for our analysis: United States, Other Rich Countries, Emerging Economies, China, Indian Subcontinent, Africa South of Sahara and Rest of World. The sequence in Table 2 follows an order of descending GDPpp per region average.

We have disregarded "region 8", which consists of a few super-rich countries outside the OECD. This cluster of countries is small ( $<1 \%$ of world population), and they are statistical outliers that distort the analysis. The global messages about SDG implementation from our analysis nevertheless also apply to these countries.

Table 2

\begin{tabular}{|c|c|c|c|c|}
\hline REGION & Country & Population & GDP & GDPpp \\
\hline & & 2015 & 2015 & 2015 \\
\hline & & $\mathrm{Mp}$ & $\mathrm{G \$} / \mathrm{y}$ & $\$ / p-y$ \\
\hline & & UN & PWT & $(=D / C)$ \\
\hline \multicolumn{5}{|l|}{ 1. United States (USA) } \\
\hline & $\begin{array}{l}\text { US, } \\
\text { Including Puerto Rico and US } \\
\text { Virgin Islands }\end{array}$ & 327 & 16705 & 51100 \\
\hline & SUM USA & 327 & 16705 & 51100 \\
\hline \multicolumn{5}{|l|}{ 2. Other Rich Countries (ORC) } \\
\hline & Australia & 23,8 & 1017 & 42700 \\
\hline & Austria & 8,7 & 407 & 46800 \\
\hline & Belgium & 11,3 & 490 & 43400 \\
\hline & Canada & 36,0 & 1507 & 41900 \\
\hline & Chile & 17,8 & 383 & 21500 \\
\hline & Czech Republic & 10,6 & 336 & 31700 \\
\hline & Denmark & 5,7 & 254 & 44600 \\
\hline & Estonia & 1,3 & 38 & 29200 \\
\hline & Finland & 5,5 & 221 & 40200 \\
\hline & France & 64,5 & 2603 & 40400 \\
\hline & Germany & 81,7 & 3707 & 45400 \\
\hline & Greece & 11,2 & 286 & 25500 \\
\hline
\end{tabular}


This is this is a non-peer reviewed preprint submitted to EarthArXiv.

\begin{tabular}{|c|c|c|c|c|}
\hline & Hungary & 9,8 & 256 & 26100 \\
\hline & Iceland & 0,3 & 14 & 46700 \\
\hline & Israel & 8,1 & 264 & 32600 \\
\hline & Italy & 59,5 & 2141 & 36000 \\
\hline & Japan & 128,0 & 4483 & 35000 \\
\hline & Luxembourg & 0,6 & 53 & 88300 \\
\hline & Netherlands & 16,9 & 797 & 47200 \\
\hline & New Zealand & 4,6 & 156 & 33900 \\
\hline & Norway & 5,2 & 331 & 63700 \\
\hline & Poland & 38,3 & 972 & 25400 \\
\hline & Portugal & 10,4 & 296 & 28500 \\
\hline & Slovakia & 5,4 & 155 & 28700 \\
\hline & Slovenia & 2,1 & 63 & 30000 \\
\hline & South Korea & 50,6 & 1758 & 34700 \\
\hline & Spain & 46,4 & 1567 & 33800 \\
\hline & Sweden & 9,8 & 433 & 44200 \\
\hline & Switzerland & 8,3 & 480 & 57800 \\
\hline & UK & 65,4 & 2589 & 39600 \\
\hline & SUM ORC & 748 & 28057 & 37500 \\
\hline \multicolumn{5}{|c|}{ 3. Emerging Economies (EE) } \\
\hline \multicolumn{5}{|c|}{ Characteristic: big mid-income countries } \\
\hline & Argentina & 43,4 & 869 & 20000 \\
\hline & Brazil & 206,0 & 3064 & 14900 \\
\hline & Iran & 79,4 & 1215 & 15300 \\
\hline & Kazakhstan & 17,8 & 407 & 22900 \\
\hline & Malaysia & 30,7 & 692 & 22500 \\
\hline & Mexico & 125,9 & 1988 & 15800 \\
\hline & Russia & 143,9 & 3448 & 24000 \\
\hline & Romania & 19,9 & 409 & 20600 \\
\hline & Thailand & 68,7 & 946 & 13800 \\
\hline & Turkey & 78,3 & 1491 & 19000 \\
\hline & Ukraine & 44,7 & 465 & 10400 \\
\hline & Venezuela & 31,2 & 434 & 13900 \\
\hline & SUMEE & 890 & 15428 & 17300 \\
\hline \multicolumn{5}{|l|}{ 4. China } \\
\hline & Taiwan & 23,5 & 1039 & 44200 \\
\hline & China & 1397,0 & 17080 & 12200 \\
\hline & Hong Kong & 7,3 & 374 & 51200 \\
\hline & SUM CHINA & 1428 & 18493 & 13000 \\
\hline
\end{tabular}


This is this is a non-peer reviewed preprint submitted to EarthArXiv.

\begin{tabular}{|c|c|c|c|c|}
\hline \multicolumn{5}{|l|}{ 5. Indian Subcontinent } \\
\hline \multicolumn{5}{|l|}{ Characteristic: poor and populous } \\
\hline & Bangladesh & 161,2 & 459 & 2800 \\
\hline & India & 1309,0 & 6767 & 5200 \\
\hline & Pakistan & 189,4 & 860 & 4500 \\
\hline & SUM INDIAN SC & 1660 & 8086 & 4900 \\
\hline \multicolumn{5}{|l|}{ 6. Africa South of Sahara (ASoS) } \\
\hline \multicolumn{5}{|l|}{ Characteristic: poor and resource rich } \\
\hline & Angola & 27,9 & 193 & 6900 \\
\hline & Cameroon & 22,8 & 61 & 2700 \\
\hline & Congo & 76,2 & 91 & 1200 \\
\hline & Cote d'Ivoire & 23,1 & 74 & 3200 \\
\hline & Ethiopia & 99,9 & 128 & 1300 \\
\hline & Ghana & 27,6 & 96 & 3500 \\
\hline & Kenya & 47,3 & 124 & 2600 \\
\hline & Madagascar & 24,2 & 29 & 1200 \\
\hline & Mozambique & 28,0 & 31 & 1100 \\
\hline & Nigeria & 181,2 & 976 & 5400 \\
\hline & Sudan & 38,6 & 190 & 4900 \\
\hline & South Africa & 55,3 & 655 & 11800 \\
\hline & Tanzania & 53,9 & 112 & 2100 \\
\hline & Uganda & 40,1 & 69 & 1700 \\
\hline & SUM AFRICA SOS & 746 & 2829 & 3800 \\
\hline \multicolumn{5}{|l|}{ 7. Rest of the World - 120 (RoW) } \\
\hline Sum world (from other data) & & 7383 & 103866 & 14100 \\
\hline Sum of regions $1-8$ & & 5847 & 92380 & 15800 \\
\hline$=$ & SUM ROW 120 & 1536 & 11486 & 7500 \\
\hline \multicolumn{5}{|l|}{ 8. Super-rich outside OECD } \\
\hline \multicolumn{5}{|l|}{ Characteristic: "authoritarian wealth" } \\
\hline & Quatar & 2,5 & 314 & 125600 \\
\hline & Saudi Arabia & 31,6 & 1483 & 46900 \\
\hline & Singapore & 5,5 & 400 & 72700 \\
\hline & UAE & 9,2 & 585 & 63600 \\
\hline & SUM SUPER-RICH & 49 & 2782 & 57000 \\
\hline MEMO & & & & \\
\hline
\end{tabular}


This is this is a non-peer reviewed preprint submitted to EarthArXiv.

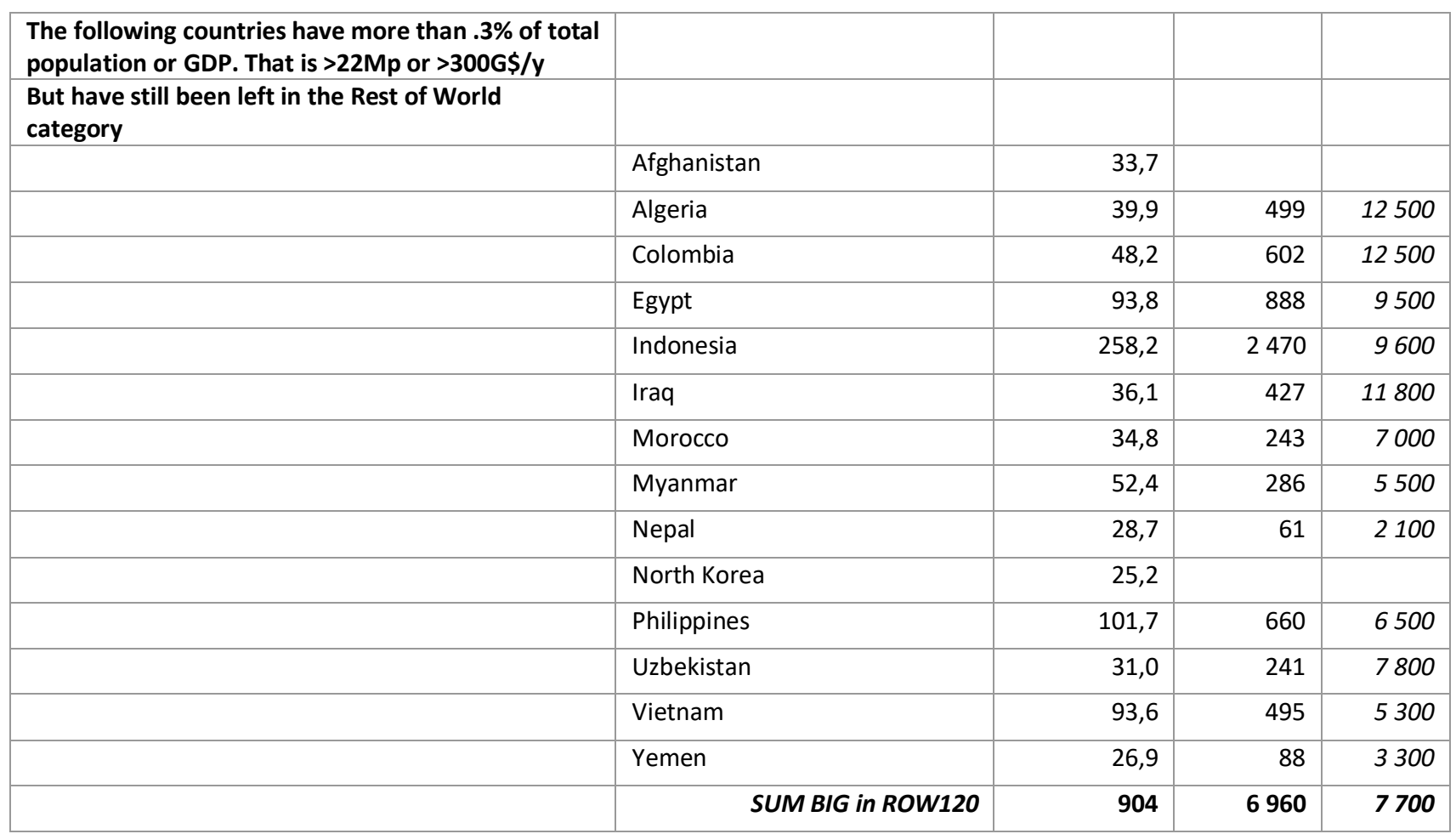


${ }^{1}$ UN Resolution A/RES/70/1, available at URL: http://undocs.org/A/RES/70/1

${ }^{2}$ Sachs J. et al. (2016): SDG Index and Dashboards - Global Report. New York: Bertelsmann Stiftung and Sustainable Development Solutions Network (SDSN). And Sachs, J.et al. (2017): SDG Index and Dashboards

${ }^{3}$ Sachs J. et al. (2016): SDG Index and Dashboards - Global Report. New York: Bertelsmann Stiftung and Sustainable Development Solutions Network (SDSN). And Sachs, J.et al. (2017): SDG Index and Dashboards Report 2017. New York: Bertelsmann Stiftung and Sustainable Development Solutions Network (SDSN).

${ }^{4}$ https://data.worldbank.org/indicator/SI.POV.DDAY

${ }^{5}$ Sachs, J.et al. (2017): SDG Index and Dashboards Report 2017. New York: Bertelsmann Stiftung and Sustainable Development Solutions Network (SDSN).

${ }^{6}$ Sachs, J.et al. (2017): SDG Index and Dashboards Report 2017. New York: Bertelsmann Stiftung and Sustainable Development Solutions Network (SDSN).

${ }^{7}$ https://data.worldbank.org/indicator/SN.ITK.DEFC.ZS

${ }^{8}$ Sachs J. et al. (2016): SDG Index and Dashboards - Global Report. New York: Bertelsmann Stiftung and Sustainable Development Solutions Network (SDSN). And Sachs, J.et al. (2017): SDG Index and Dashboards Report 2017. New York: Bertelsmann Stiftung and Sustainable Development Solutions Network (SDSN).

${ }^{9} \mathrm{http}: / /$ data.un.org/Data.aspx?d=PopDiv\&f=variablelD\%3A68

${ }^{10}$ Sachs J. et al. (2016): SDG Index and Dashboards - Global Report. New York: Bertelsmann Stiftung and Sustainable Development Solutions Network (SDSN). And Sachs, J.et al. (2017): SDG Index and Dashboards Report 2017. New York: Bertelsmann Stiftung and Sustainable Development Solutions Network (SDSN).

${ }^{11}$ United Nations Development Programme Human Development Reports, http://www.hdr.undp.org

${ }^{12}$ Sachs J. et al. (2016): SDG Index and Dashboards - Global Report. New York: Bertelsmann Stiftung and Sustainable Development Solutions Network (SDSN). And Sachs, J.et al. (2017): SDG Index and Dashboards Report 2017. New York: Bertelsmann Stiftung and Sustainable Development Solutions Network (SDSN).

${ }^{13}$ United Nations General Assembly Resolution A/RES/70/1 Transforming our world: the 2030 Agenda for Sustainable Development

${ }^{14}$ http://datatopics.worldbank.org/education/

${ }^{15} \mathrm{http} / / /$ datatopics.worldbank.org/education/

${ }^{16} \mathrm{https}: / /$ data.worldbank.org/indicator/SH.H2O.BASW.ZS

${ }^{17}$ https://data.worldbank.org/indicator/EG.ELC.ACCS.ZS

${ }^{18}$ Sachs J. et al. (2016): SDG Index and Dashboards - Global Report. New York: Bertelsmann Stiftung and Sustainable Development Solutions Network (SDSN). And Sachs, J.et al. (2017): SDG Index and Dashboards Report 2017. New York: Bertelsmann Stiftung and Sustainable Development Solutions Network (SDSN).

${ }^{19}$ Sachs J. et al. (2016): SDG Index and Dashboards - Global Report. New York: Bertelsmann Stiftung and Sustainable Development Solutions Network (SDSN). And Sachs, J.et al. (2017): SDG Index and Dashboards Report 2017. New York: Bertelsmann Stiftung and Sustainable Development Solutions Network (SDSN).

${ }^{20}$ Feenstra, Robert C., Robert Inklaar and Marcel P. Timmer (2015), "The Next Generation of the Penn World Table" American Economic Review, 105(10), 3150-3182, available for download at www.ggdc.net/pwt

${ }^{21}$ United Nations, Department of Economic and Social Affairs, Population Division (2017). World Population Prospects: The 2017 Revision, DVD Edition. Accessed at https://esa.un.org/unpd/wpp/Download/Standard/Population/ 22 https://data.worldbank.org/indicator/NV.IND.TOTL.ZS, https://data.worldbank.org/indicator/NV.IND.MANF.ZS, https://data.worldbank.org/indicator/NV.AGR.TOTL.ZS and https://data.worldbank.org/indicator/NV.SRV.TETC.ZS

${ }^{23}$ Sachs, J.et al. (2017): SDG Index and Dashboards Report 2017. New York: Bertelsmann Stiftung and Sustainable Development Solutions Network (SDSN).

${ }^{24}$ Available at http://wid.world/data/

${ }^{25}$ https://data.worldbank.org/indicator/en.atm.pm25.mc.m3

${ }^{26} \mathrm{http} / / /$ www.euro.who.int/_data/assets/pdf_file/0019/331660/Evolution-air-quality.pdf?ua=1

${ }^{27}$ Data available from https://www.footprintnetwork.org/licenses/public-data-package-free-2018/ 
${ }^{28}$ https://www.ncdc.noaa.gov/cag/global/time-series

${ }^{29}$ https://www.pmel.noaa.gov/co2/story/WHOTS

${ }^{30} \mathrm{http} / / / \mathrm{bats} \cdot$ bios.edu/

${ }^{31} \mathrm{http}: / / \mathrm{www}$.fao.org/forest-resources-assessment/en/

${ }^{32}$ Steffen W, Richardson K, Rockström J, Cornell SE, Fetzer I, Bennett EM, Biggs R, Carpenter SR, Vries W de, Wit CA de, Folke C, Gerten D, Heinke J, Mace GM, Persson LM, Ramanathan V, Reyers B, Sörlin S (2015) Planetary boundaries: Guiding human development on a changing planet. Science 1259855. doi: 10.1126/science.1259855 ${ }^{33}$ Rockström, J., W. Steffen, K. Noone, Å. Persson, F. S. Chapin, III, E. Lambin, T. M. Lenton, M. Scheffer, C. Folke, H. Schellnhuber, B. Nykvist, C. A. De Wit, T. Hughes, S. van der Leeuw, H. Rodhe, S. Sörlin, P. K. Snyder, R. Costanza, U. Svedin, M. Falkenmark, L. Karlberg, R. W. Corell, V. J. Fabry, J. Hansen, B. Walker, D. Liverman, K. Richardson, P. Crutzen, and J. Foley. 2009. Planetary boundaries: exploring the safe operating space for humanity. Ecology and Society 14(2): 32. [online] URL: http://www.ecologyandsociety.org/vol14/iss2/art32/

${ }^{34}$ www.2052.info/ESCIMO

${ }^{35}$ Feely RA, Doney SC, Cooley SR. 2009. Ocean acidification: Present conditions and future changes in a high-CO2 world. Oceanography 22:4. [online] URL: https://darchive.mblwhoilibrary.org/bitstream/handle/1912/3180/22-

4_feely.pdf?sequence $=1$

${ }^{36} \mathrm{https}: / /$ www.pmel.noaa.gov/co2/story/WHOTS

${ }^{37}$ http://bats.bios.edu/

${ }^{38} \mathrm{Giam}, \mathrm{X}$. 2017. Gloal biodiversity loss from tropical deforestation. PNAS 114:2. [online] http://www.pnas.org.ezp.sub.su.se/content/114/23/5775

${ }^{39} \mathrm{http}: / / \mathrm{www}$.fao.org/forest-resources-assessment/en/

${ }^{40}$ Steffen W, Richardson K, Rockström J, Cornell SE, Fetzer I, Bennett EM, Biggs R, Carpenter SR, Vries W de, Wit CA de, Folke C, Gerten D, Heinke J, Mace GM, Persson LM, Ramanathan V, Reyers B, Sörlin S (2015) Planetary boundaries: Guiding human development on a changing planet. Science 1259855. doi: 10.1126/science.1259855

${ }^{41}$ Rockström, J., W. Steffen, K. Noone, Å. Persson, F. S. Chapin, III, E. Lambin, T. M. Lenton, M. Scheffer, C. Folke, H. Schellnhuber, B. Nykvist, C. A. De Wit, T. Hughes, S. van der Leeuw, H. Rodhe, S. Sörlin, P. K. Snyder, R. Costanza, U. Svedin, M. Falkenmark, L. Karlberg, R. W. Corell, V. J. Fabry, J. Hansen, B. Walker, D. Liverman, K. Richardson, P. Crutzen, and J. Foley. 2009. Planetary boundaries: exploring the safe operating space for humanity. Ecology and Society 14(2): 32. [online] URL: http://www.ecologyandsociety.org/vol14/iss2/art32/

${ }^{42}$ Data available from https://www.footprintnetwork.org/licenses/public-data-package-free-2018/

${ }^{43} \mathrm{https}: / /$ data.worldbank.org/indicator/en.atm.pm25.mc.m3

${ }^{44}$ https://www.ila-lead.org/lead-facts/lead-production--statistics

${ }^{45}$ Feenstra, Robert C., Robert Inklaar and Marcel P. Timmer (2015), "The Next Generation of the Penn World Table" American Economic Review, 105(10), 3150-3182 